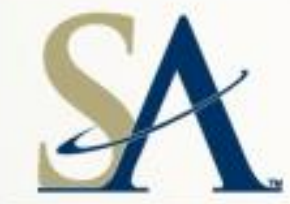

STRATEGIC ANALYSISZ

\title{
PEM Electrolysis H2A Production Case Study Documentation
}

\author{
Prepared for the U.S. Department of Energy
}

Fuel Cell Technologies Office

31 December 2013

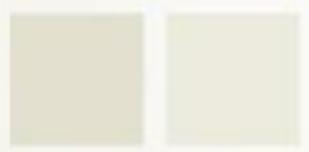

By:

Brian James (SA)

Whitney Colella (SA)

Jennie Moton (SA)
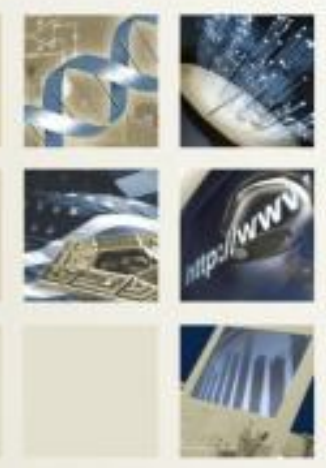

and from the

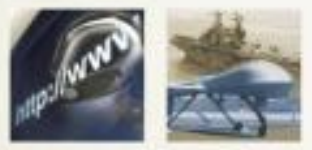

National Renewable Energy Laboratory (NREL)
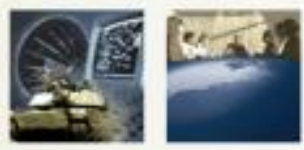

Genevieve Saur (NREL)

Todd Ramsden (NREL)

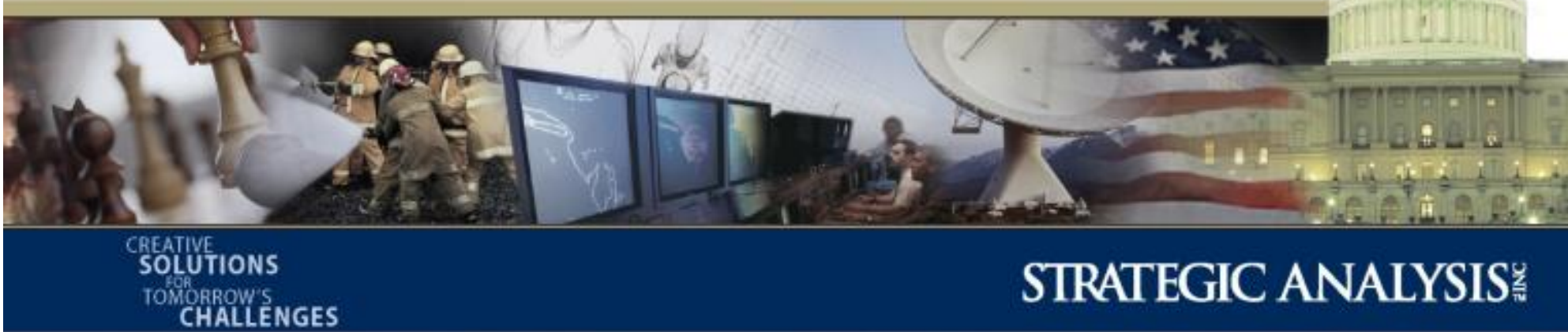

This report does not contain any proprietary, confidential, or otherwise restricted information. 


\section{Sponsorship}

This research was conducted under contract to the U.S. Department of Energy's Energy Efficiency and Renewable Energy Fuel Cell Technologies Office, under award number DE-EE0006231.

\section{Authors' Contact Information}

Strategic Analysis Inc. may be contacted at:

Strategic Analysis Inc. (SA)

4075 Wilson Blvd, Suite 200

Arlington, VA 22203

(703) 527-5410

www.sainc.com

The corresponding authors may be contacted at:

Brian D. James

Director of Energy Programs

(703) 778-7114

BJames@sainc.com

Whitney G. Colella

Principal Research Engineer

(703) 253-4729

WColella@sainc.com 


\section{Table of Contents}

\section{Contents}

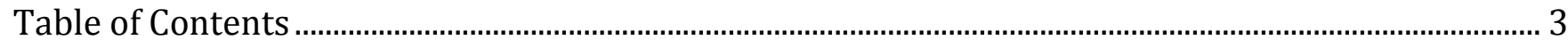

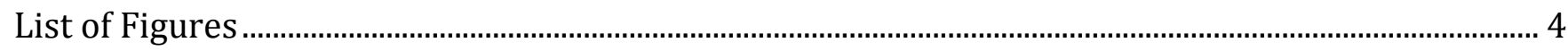

List of Tables.....................................................................................................................................

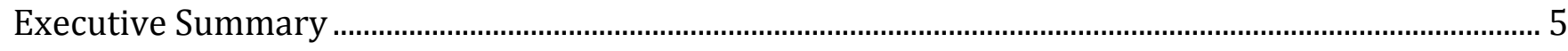

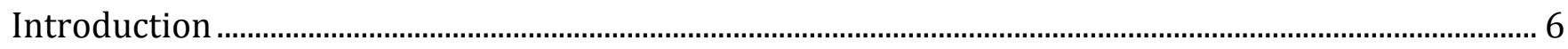

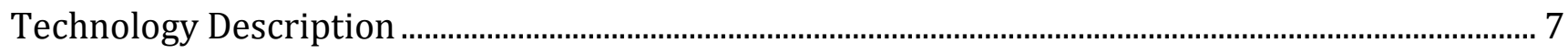

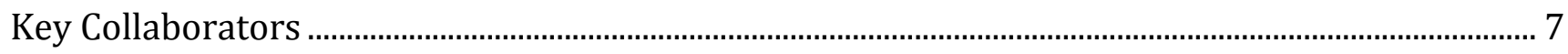

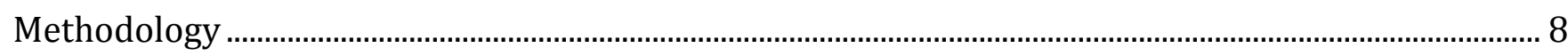

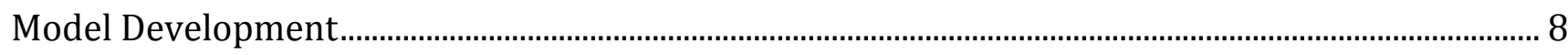

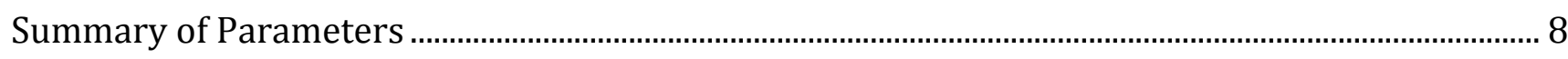

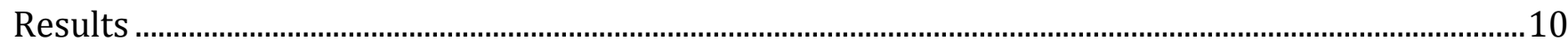

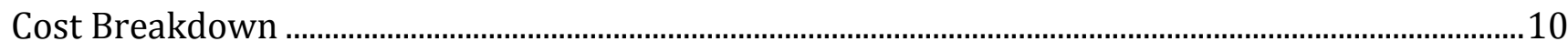

Sensitivity Analysis and Tornado Charts..................................................................................................12

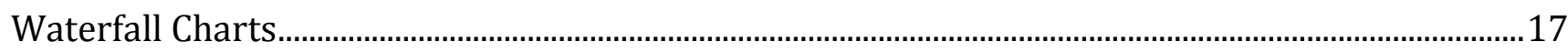

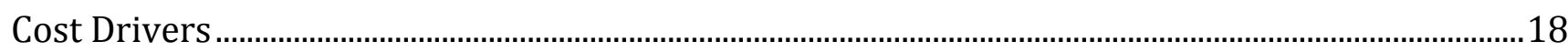

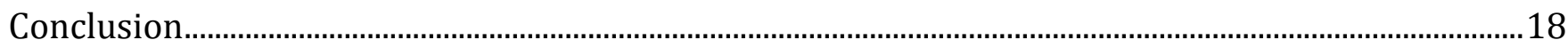

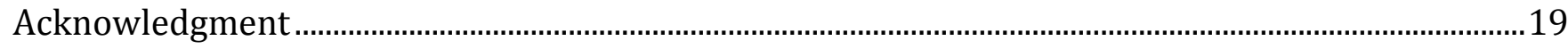

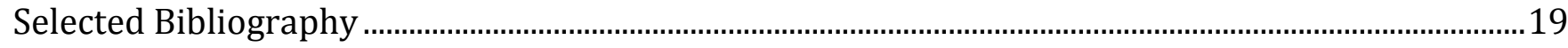

Publically Available Documentation for 2013 PEM Electrolysis H2A Study …………………………....19

Appendix A. Electrolysis Questionnaire...........................................................................................................20 


\section{List of Figures}

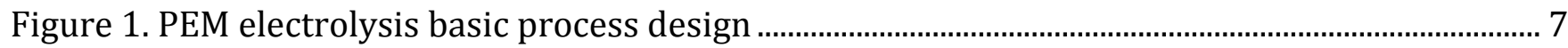

Figure 2. PEM electrolyzer water splitting process ............................................................................. 7

Figure 3. H2A Production PEM electrolysis breakdown (cost results reported in 2007\$; average electricity prices for the Current and Future cases are $\sim 6.22 థ / \mathrm{kWh}$ and $\sim 6.88 థ / \mathrm{kWh}$,

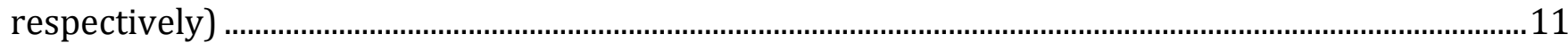

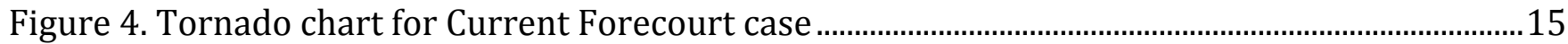

Figure 5. Tornado chart for Future Forecourt case ............................................................................15

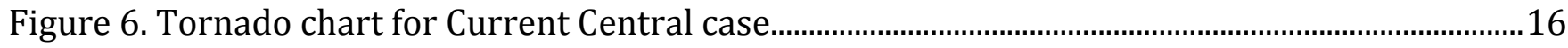

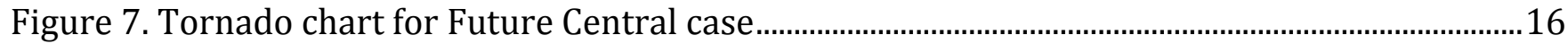

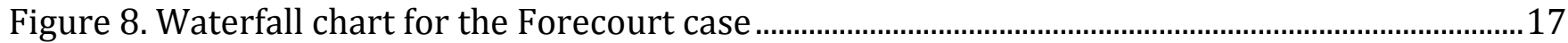

Figure 9. Waterfall chart for the Central case .........................................................................................18

Figure 10. Forecourt case questionnaire tab (continued) ...........................................................................23

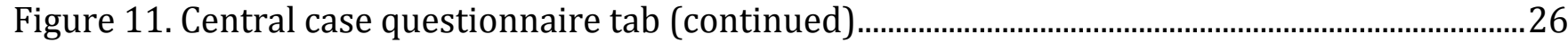

Figure 12. Additional Technical Detail questionnaire tab ......................................................................27

\section{List of Tables}

Table 1. H2A input model assumptions for the four cases .................................................................... 6 Table 2. Major parameters used in H2A Production cases for PEM electrolysis (costs parameters in $2007 \$$ and in $2012 \$$ )

Table 3. Cost breakdown for H2A Production PEM electrolysis baseline cases (cost results reported in $2007 \$$ ).

Table 4. Breakdown of sensitivities for the Forecourt cases (cost results reported in $2007 \$$ and variable limits reported in $2007 \$$ and $2012 \$$ )

Table 5. Breakdown of sensitivities for the Central cases (cost results reported in $2007 \$$ and variable limits reported in $2007 \$$ and $2012 \$$ ). 


\section{PEM Electrolysis H2A Production Case Study Documentation}

\section{Executive Summary}

This report details analysis of hydrogen $\left(\mathrm{H}_{2}\right)$ production based on polymer electrolyte membrane (PEM) electrolysis. This work identifies primary constraints to the success of this production pathway, primary cost drivers, and remaining Research and Development (R\&D) challenges. This research assesses the potential to meet U.S. Department of Energy (DOE) $\mathrm{H}_{2}$ production and delivery (P\&D) cost goals of less than \$4/gasoline gallon equivalent (dispensed, untaxed) by 2020.

Pathway analysis is performed using the DOE's main H2A modeling tool, namely, the H2A Production model, which encapsulates the standard methods of energy, emissions, and cost analysis developed by DOE's $\mathrm{H}_{2}$ and fuel cell technology teams. The following methodology is applied to the PEM electrolysis production pathway:

- Literature review;

- Industry survey covering PEM electrolyzer economic and engineering performance;

- System definition covering energy efficiency, environmental, and economic estimates;

- H2A model spreadsheet runs with the gathered information;

- Sensitivity analyses (tornado and/or waterfall charts) to identify key cost drivers;

- Documentation of case study results; and

- Case vetting with team partners and with others.

PEM electrolysis production pathways are analyzed for a distributed, forecourt $\mathrm{H}_{2}$ production system of 1,500 kilograms $(\mathrm{kg})$ of $\mathrm{H}_{2}$ per day, and for a central, large, plant size $\mathrm{H}_{2}$ production system of 50,000 $\mathrm{kg} \mathrm{H}_{2}$ /day, for both current and future cases. The analysis is based in part on data from a technical and economic survey completed by four different PEM electrolyzer companies.

Model results indicate that, for PEM electrolysis, the primary cost drivers are the electricity expenditures to run the electrolyzer and the capital cost of the electrolyzer. In the future within the electrolyzer system, the balance of plant is expected to be a greater source of cost than the electrolyzer stack due to stack reductions facilitated by operation at higher current densities whereas the balance of plant remains similarly sized for the given flow. This balance between size and cost of the stack versus balance of plant could also increase difficulties in meeting efficiency improvements in the future. The $\mathrm{H}_{2}$ cost reduction is estimated to be greater moving from a Current case to a Future case, compared with moving from a Forecourt case to a Central case. 


\section{Introduction}

This report documents the development of four H2A Production case studies for polymer electrolyte membrane (PEM) electrolysis. The four cases characterize PEM electrolyzer technology for two hydrogen $\left(\mathrm{H}_{2}\right)$ production plant sizes (Forecourt ${ }^{1}$ and Central) and for two technology development time horizons (Current and Future). Table 1 shows H2A input model assumptions for the technology development year ${ }^{2}$ (either year 2013 or 2025), the $\mathrm{H}_{2}$ production plant start date (either year 2010 or 2025), ${ }^{3} \mathrm{H}_{2}$ production rates (in units of kilograms (kg) of $\mathrm{H}_{2}$ per day), and plant lifetime (in years) for the four cases.

Table 1. H2A input model assumptions for the four cases

\begin{tabular}{lcccc}
\hline Case & $\begin{array}{c}\text { Technology } \\
\text { Development } \\
\text { Year }\end{array}$ & $\begin{array}{c}\mathbf{H}_{2} \text { Plant } \\
\text { Start Date }\end{array}$ & $\begin{array}{c}\mathbf{H}_{2} \text { Production Rate } \\
\text { (kg H } / \text { day) }\end{array}$ & $\begin{array}{c}\text { Plant Lifetime } \\
\text { (years) }\end{array}$ \\
\hline $\begin{array}{l}\text { Current } \\
\text { Forecourt }\end{array}$ & 2013 & 2010 & 1,5004 & 20 \\
Current Central & 2013 & 2010 & 50,000 & 40 \\
Future Forecourt & 2025 & 2025 & 1,500 & 20 \\
Future Central & 2025 & 2025 & 50,000 & 40 \\
\hline
\end{tabular}

"Current" cases assume a short-term projection from technology that is commercially available or that has been demonstrated in the lab in terms of technology readiness level. Current cases assume advances that already have been demonstrated in individual components are simultaneously able to be successfully implemented in a full-scale system. Current cases also assume that equipment capital costs are reduced by high-volume manufacturing and the resulting economies of scale. Current technology generally references only advancements that could be incorporated into a commercial product with a high degree of confidence, fairly quickly, and with little risk.

In contrast to Current cases, Future cases project the development of the technology with new materials and capabilities and improved hydrogen production efficiencies, and include longer equipment lifetimes. Generally, capital costs of the systems are further reduced, compared with the Current case.

\footnotetext{
${ }^{1}$ Hydrogen production cost is the focus of the case study. For the Forecourt cases, compression, storage, and dispensing computations are included in the base H2A spreadsheet, and thus they are also reported in the case study.

2 Technology development year is defined as the year in which a system design and performance level have been demonstrated in the laboratory with high confidence that it can be developed into a full-scale system able to achieve performance, durability, and cost targets.

3 Plant start date (2010) occurs before Technology Year (2013) because it is H2A practice to begin all Current cases in a common year for ease of comparison. For example, the start date affects the price of electricity based on the Annual Energy Outlook (AEO) lookup table.

${ }^{4}$ As a variation on the standard Current Forecourt case, an analysis at a $500 \mathrm{~kg} /$ day capacity (more representative of expected early market stations) was also performed with inputs from the manufacturers.
} 


\section{Technology Description}

PEM water electrolysis uses electrical power to split water $\left(\mathrm{H}_{2} \mathrm{O}\right)$ into oxygen $\left(\mathrm{O}_{2}\right)$ and $\mathrm{H}_{2}$. A schematic diagram of the basic process is shown in Figure 1. A schematic diagram of the water splitting processes within the PEM electrolyzer stack is shown in Figure 2. As shown in Figure 2, at the positive terminal (the anode), water reacts under the influence of a catalyst to form oxygen molecules, electrons $\left(\mathrm{e}^{-}\right)$, and hydrogen protons $\left(\mathrm{H}^{+}\right)$. Hydrogen protons are conducted across the PEM electrolyte, while the electrons flow through an external power circuit. At the negative terminal (the cathode), the electrons combine with the hydrogen protons to produce $\mathrm{H}_{2}$.

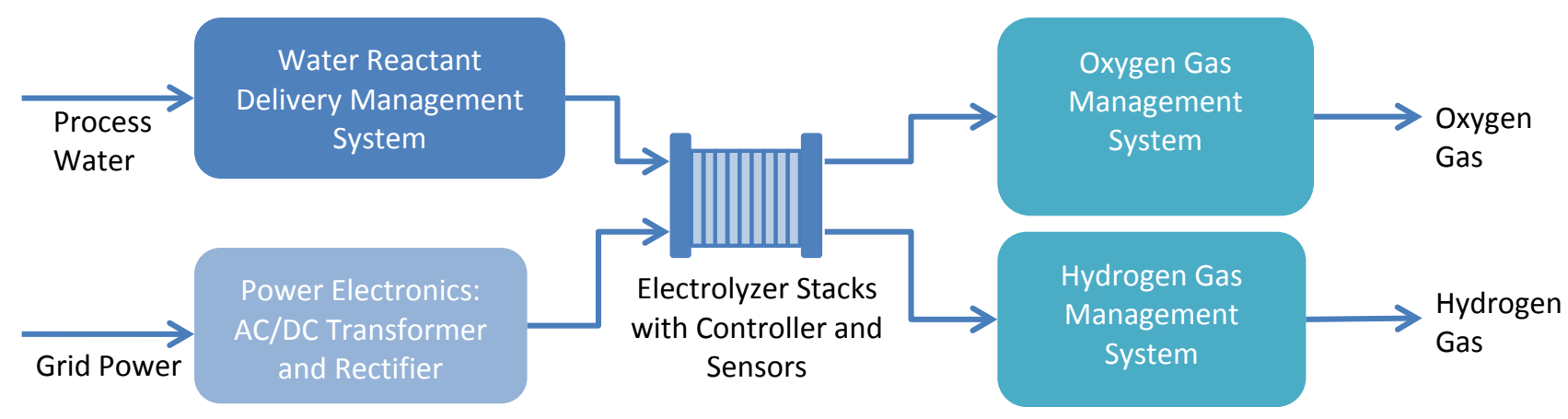

* Oxygen gas generated but currently modeled as being released into the atmosphere

Figure 1. PEM electrolysis basic process design

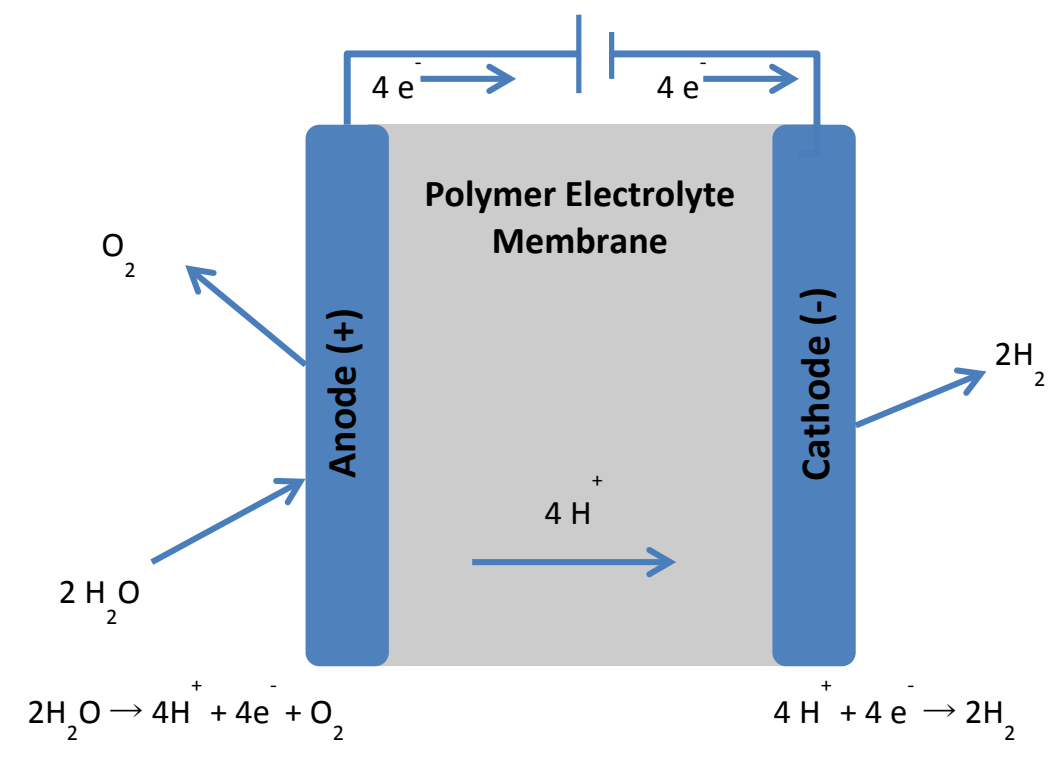

Figure 2. PEM electrolyzer water splitting process

\section{Key Collaborators}

Four electrolyzer companies provided input for development of the generic PEM electrolysis cases. A team from Strategic Analysis Inc. (SA) and the National Renewable Energy Laboratory (NREL) performed analysis and case study preparation. Interactive technical oversight was 
provided by a team from the U.S. Department of Energy (DOE). Questions can be directed to the DOE’s H2A 5 webmaster: hydrogen_doeh2a@nrel.gov.

\section{Methodology}

\section{Model Development}

Relevant engineering and economic information was solicited from the four electrolyzer companies. A questionnaire spreadsheet, detailed in Appendix A, was used to gather data. The requested data included $\mathrm{H} 2 \mathrm{~A}$ input parameters needed for developing cases, along with some additional information for understanding the underlying technology assumptions.

The data collected were synthesized and amalgamated into generalized cases that were broadly representative of the data collected. The four companies vetted this synthesized and amalgamated data, as well as select sensitivity limit parameters. Data collected fell into the following five primary categories:

1. Engineering system definition,

2. Capital costs,

3. Operating costs,

4. Variable and fixed expenses, and

5. Replacement costs.

An engineering system performance model was also generated using additional parameters provided by the companies, so as to create a generalized electrolyzer system engineering design based upon diverse industry input. This model was used to corroborate selected parameter values for the four case studies.

Data from the four generalized cases (i.e., Current Forecourt, Current Central, Future Forecourt, and Future Central) were used to populate the H2A Distributed and Central Hydrogen Production Models (both Version 3.0) and to generate estimates of hydrogen cost. Sensitivity analysis in the form of waterfall and tornado charts was conducted using the H2A model.

\section{Summary of Parameters}

Major parameters used to develop the four case studies are shown inTable 2. Parameters not cited here were assumed to be in accordance with standard H2A default values. Although the PEM electrolyzer net system electrical efficiency is estimated to rise from $61 \%$ in the Current case to $66 \%$ in the Future case, the average electricity price is estimated to rise from $6.12 \mathrm{q} / \mathrm{kWh}$ to $6.88 \$ / \mathrm{kWh}$ between these cases as well. ${ }^{6}$

Note that Table 2 lists electrolyzer capital costs in U.S. 2012 dollars (2012\$) because that is the reporting year for the four electrolyzer companies. However, hydrogen cost results $(\$ / \mathrm{kg})$ will

\footnotetext{
${ }^{5} \mathrm{http}: / /$ www.hydrogen.energy.gov/h2a_production.html

${ }^{6}$ Average Current Forecourt electricity price $(6.12 థ / \mathrm{kWh})$ is less than the average Current Central electricity price $(6.22 \Phi / \mathrm{kWh})$ because of the different time horizons for the investment, namely 20 years versus 40 years. The same pattern holds for the Future cases. H2A default electricity price input values are based on U.S. Energy Information Administration (EIA) Annual Energy Outlook (AEO) industrial electricity price values, which generally escalate over time. As a result, investments over a shorter time horizon (i.e. 20 years versus 40 years) will have a lower average electricity price.
} 
always be reported in 2007 dollars (2007\$), according to the standard H2A methodology approved by DOE.

Table 2. Major parameters used in H2A Production cases for PEM electrolysis (costs parameters in 2007\$ and in 2012\$)

\begin{tabular}{|c|c|c|c|c|}
\hline Parameter & $\begin{array}{c}\text { Current } \\
\text { Forecourt }\end{array}$ & $\begin{array}{c}\text { Future } \\
\text { Forecourt }\end{array}$ & $\begin{array}{l}\text { Current } \\
\text { Central }\end{array}$ & $\begin{array}{l}\text { Future } \\
\text { Central }\end{array}$ \\
\hline Plant Capacity (kg/day) & 1,500 & 1,500 & 50,000 & 50,000 \\
\hline $\begin{array}{l}\text { Total Uninstalled Capital (2012\$/kilowatt } \\
(\mathrm{kW}))\end{array}$ & $\$ 940$ & $\$ 450$ & $\$ 900$ & $\$ 400$ \\
\hline Stack Capital Cost (2012\$/kW) & $\$ 385$ & $\$ 171$ & $\$ 423$ & $\$ 148$ \\
\hline $\begin{array}{l}\text { Balance of Plant (BOP) Capital } \\
\text { Cost }(2012 \$ / \mathrm{kW})\end{array}$ & $\$ 555$ & $\$ 279$ & $\$ 477$ & $\$ 252$ \\
\hline $\begin{array}{l}\text { Total Electrical Usage (kilowatt-hour } \\
(\mathrm{kWh}) / \mathrm{kg})\end{array}$ & 54.6 & 50.3 & 54.3 & 50.2 \\
\hline $\begin{array}{l}\text { Net System Electrical Efficiency } \\
\text { (percentage (\%) of lower heating value } \\
\text { (LHV) of } \mathrm{H}_{2} \text { input energy) }\end{array}$ & $61 \%$ & $66 \%$ & $61 \%$ & $66 \%$ \\
\hline $\begin{array}{l}\text { Stack Electrical Usage }(\mathrm{kWh} / \mathrm{kg}) \\
\left(\% \mathrm{LHV} \mathrm{H}_{2}\right)\end{array}$ & $\begin{array}{c}49.2 \\
(68 \%)\end{array}$ & $\begin{array}{c}46.7 \\
(71 \%)\end{array}$ & $\begin{array}{c}49.2 \\
(68 \%)\end{array}$ & $\begin{array}{c}46.7 \\
(71 \%)\end{array}$ \\
\hline BOP Electrical Usage (kWh/kg) & 5.4 & 3.6 & 5.1 & 3.5 \\
\hline $\begin{array}{l}\text { Electrolyzer Power Consumption } \\
\text { (Megawatts (MW)) }\end{array}$ & 3.4 & 3.1 & 113.1 & 104.6 \\
\hline $\begin{array}{l}\text { Average Electricity Price over Life of } \\
\text { Plant }^{7}(2007 \$ / k W h)\end{array}$ & 6.12 & 6.88 & 6.22 & 6.89 \\
\hline $\begin{array}{l}\text { Electricity Price in Startup Year (H2A } \\
\text { Default Values) }{ }^{8}(2007 \$ / \mathrm{kWh})\end{array}$ & 5.74 & 6.59 & 5.74 & 6.59 \\
\hline $\begin{array}{l}\text { Hydrogen Outlet Pressure (pounds per } \\
\text { square inch) }\end{array}$ & 450 & 1,000 & 450 & 1,000 \\
\hline $\begin{array}{l}\text { Installation Cost (\% of uninstalled capital } \\
\text { cost) }\end{array}$ & $12 \%$ & $10 \%$ & $12 \%$ & $10 \%$ \\
\hline Replacement Interval (years) & 7 & 10 & 7 & 10 \\
\hline $\begin{array}{l}\text { Replacement Cost of Major Components } \\
\text { (\% of installed capital cost) }\end{array}$ & $15 \%$ & $12 \%$ & $15 \%$ & $12 \%$ \\
\hline
\end{tabular}

${ }^{7}$ Average electricity price over life of plant (20 years for Forecourt cases and 40 years for Central cases).

${ }^{8}$ H2A Default Values from Energy Information Administration (EIA) Annual Energy Outlook (AEO) data. 


\section{Results}

\section{Cost Breakdown}

The cost breakdown for the four H2A Production PEM electrolysis baseline cases is shown in Table 3; results are shown in 2007 dollars. As shown in the table, the primary cost driver for production is the feedstock fuel cost, which is primarily composed of the electricity expenditures for the electrolyzer stack. Although the electrolyzer electrical efficiency increases between the Current and Future cases, the electricity price also rises, and, as a result of this combined effect and other factors, feedstock costs are slightly higher for the Future cases. Forecourt costs for the hydrogen CSD elements at the hydrogen refueling station are also shown in Table 3. Production cost, not CSD cost, is the focus of the analysis, and CSD costs are reported only because they are included in the H2A Distributed Production Model. H2A standard parameter values were used for all CSD assumptions. CSD-associated costs are not calculated for the Central cases.

Table 3. Cost breakdown for H2A Production PEM electrolysis baseline cases (cost results reported in 2007\$)

\begin{tabular}{|c|c|c|c|c|}
\hline Component & $\begin{array}{c}\text { Current } \\
\text { Forecourt }\end{array}$ & $\begin{array}{c}\text { Future } \\
\text { Forecourt }\end{array}$ & $\begin{array}{l}\text { Current } \\
\text { Central }\end{array}$ & $\begin{array}{l}\text { Future } \\
\text { Central }\end{array}$ \\
\hline $\begin{array}{l}\text { Production Cost } \\
(2007 \$ / \mathrm{kg})\end{array}$ & $\$ 5.14^{9}$ & $\$ 4.23$ & $\$ 5.12$ & $\$ 4.20$ \\
\hline Capital Cost & $\$ 1.35$ & $\$ 0.58$ & $\$ 1.33$ & $\$ 0.53$ \\
\hline Stack Capital Cost & $\$ 0.42$ & $\$ 0.16$ & $\$ 0.48$ & $\$ 0.17$ \\
\hline BOP Capital Cost & $\$ 0.61$ & $\$ 0.26$ & $\$ 0.54$ & $\$ 0.26$ \\
\hline $\begin{array}{l}\text { Indirect Capital Cost } \\
\text { and Replacement Cost }\end{array}$ & $\$ 0.32$ & $\$ 0.16$ & $\$ 0.31$ & $\$ 0.10$ \\
\hline Decommissioning & $\$ 0.02$ & $\$ 0.00$ & $\$ 0.00$ & $\$ 0.00$ \\
\hline $\begin{array}{l}\text { Fixed operations and } \\
\text { maintenance (O\&M) }\end{array}$ & $\$ 0.42$ & $\$ 0.18$ & $\$ 0.40$ & $\$ 0.20$ \\
\hline Feedstock & $\$ 3.34$ & $\$ 3.46$ & $\$ 3.38$ & $\$ 3.46$ \\
\hline Variable O\&M & $\$ 0.01$ & $\$ 0.01$ & $\$ 0.01$ & $\$ 0.01$ \\
\hline $\begin{array}{l}\text { CSD Cost (Forecourt only) } \\
(2007 \$ / \mathrm{kg})^{10}\end{array}$ & $\$ 2.44$ & $\$ 1.56$ & \multirow{4}{*}{\multicolumn{2}{|c|}{ Not Applicable }} \\
\hline CSD Capital Cost & $\$ 1.53$ & $\$ 0.92$ & & \\
\hline CSD Fixed O\&M & $\$ 0.54$ & $\$ 0.38$ & & \\
\hline CSD Variable O\&M & $\$ 0.37$ & $\$ 0.26$ & & \\
\hline $\begin{array}{l}\text { Production + CSD Cost } \\
(2007 \$ / \mathrm{kg})\end{array}$ & $\begin{array}{c}\$ 7.58 \\
\text { (Prod. \& CSD) }\end{array}$ & $\begin{array}{c}\$ 5.79 \\
\text { (Prod. \& CSD) }\end{array}$ & $\begin{array}{c}\$ 5.12 \\
\text { (Prod. only) }\end{array}$ & $\begin{array}{c}\$ 4.20 \\
\text { (Prod. only) }\end{array}$ \\
\hline
\end{tabular}

\footnotetext{
${ }^{9}$ For the "Early Market Current Forecourt Case" analyzed at a capacity of $500 \mathrm{~kg} /$ day H2, the projected cost is increased to $\$ 5.79 / \mathrm{kg}$ (in $2007 \$$ ).

${ }^{10}$ Hydrogen production cost is the focus of the case study. For the Forecourt cases, compression, storage, and dispensing computations are included in the base H2A spreadsheet, and thus they are also reported in the case study. The CSD cost difference from the current to future case is reduced slightly by the change in output pressure from electrolyzer ( 450 psi to $1,000 \mathrm{psi}$, see Table 2), but the cost change is more greatly affected by design differences that include higher efficiency compressors, more reliable compressors (allowing for one unit to be installed rather than two with a backup), lower cost dispensers, and higher electricity price.
} 
The baseline projections shown in Table 3 incorporate averaged amalgamations of the electrolyzer stack and balance of plant (BOP) costs supplied by the four independent manufacturers; and these values (along with all technoeconomic inputs to the baseline cases shown in Table 2) were discussed with and vetted by the manufacturers.

Figure 3 plots the levelized production cost of $\mathrm{H}_{2}$ on the y-axis for the four baseline cases, as well as the cost breakdown for each case. The vertical bars around each of the baseline total costs reflect the low and high projections for each case based solely on the low and high limits for uninstalled capital costs (including stack, balance of plant (BOP)) shown in Table 4 and Table $5{ }^{11 .}$

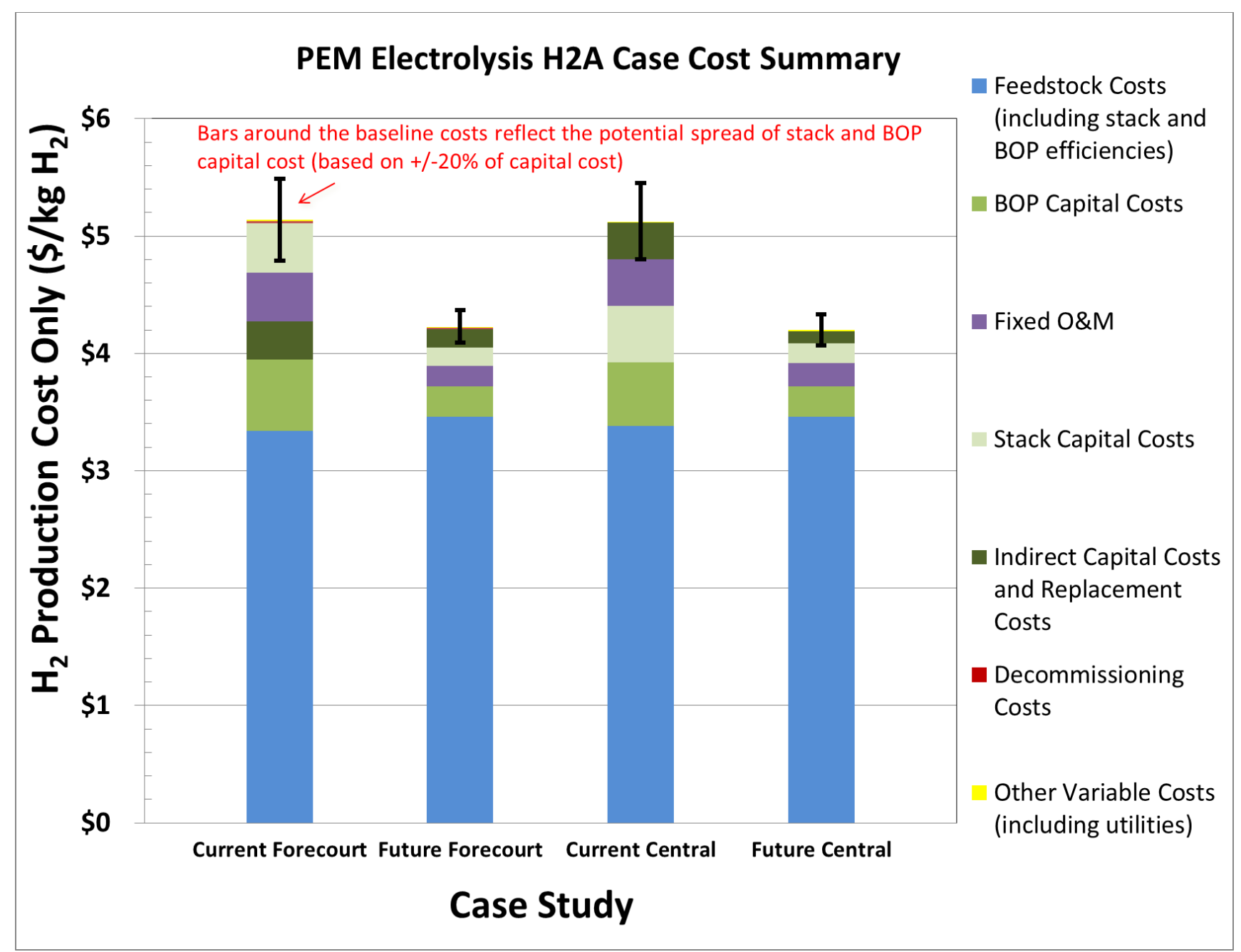

Figure 3. H2A Production PEM electrolysis breakdown (cost results reported in 2007\$; average electricity prices for the Current and Future cases are $\sim 6.22 థ / \mathrm{kWh}$ and $\sim 6.88 \pitchfork / \mathrm{kWh}$, respectively)

H2A model results indicate that the most sensitive input parameter is the feedstock costs, and in particular, the cost of electricity input to the electrolyzer. As noted in Table 2, the average electricity price over the life of the plant is $6.12 \mathrm{~d} / \mathrm{kWh}$ in the Current Forecourt case, $6.88 \mathrm{~d} / \mathrm{kWh}$ in the Future Forecourt case, $6.22 \mathrm{c} / \mathrm{kWh}$ in the Current Central case, and $6.89 \mathrm{q} / \mathrm{kWh}$ in the Future Central case. Either lower electricity prices or higher electrolyzer efficiencies can help reduce feedstock costs. The second most sensitive input parameter is the capital cost of the

\footnotetext{
${ }^{11}$ Actual lower and upper bounds on capital cost from the independent electrolyzer manufacturers are considered proprietary and thus are not specified.
} 
electrolyzer equipment, including the costs of the electrolyzer stack and the BOP. In the future within the electrolyzer system, the balance of plant is expected to be a greater source of cost than the electrolyzer stack due to stack reductions facilitated by operation at higher current densities whereas the balance of plant remains similarly sized for the given flow. This balance between size and cost of the stack versus balance of plant could also increase difficulties in meeting efficiency improvements in the future. Results indicate that the $\mathrm{H}_{2}$ cost reduction is expected to be greater moving from a Current case to a Future case, compared with moving from a Forecourt case to a Central case.

By default, the H2A case studies vary feedstock and utility costs yearly according to the yearly predictions from the 2009 Annual Energy Outlook ${ }^{12}$ (AEO) from the U.S. Energy Information Administration (EIA). Thus, for the PEM electrolyzer cases, electricity price changes each year starting with the EIA projection for the starting year and ending in the final year of the analysis (20 years later for Forecourt and 40 years later for Central). Industrial ${ }^{13}$ electricity prices are used for all cases.

\section{Sensitivity Analysis and Tornado Charts}

Table 4 details the range of parameter values used within the sensitivity analysis. The four electrolyzer companies vetted these sensitivity limits, which were suggested by the analysis team, and which are meant to capture the potential range of parameter variation rather than to report the minimum and maximum values from the four companies.

These input parameters were chosen based on whether they were believed to have a high impact on the cost of hydrogen, whether there was a large uncertainty as to their precise value, and whether there was a perception of a significant opportunity for improvement with further R\&D, learning and experience, and/or time. Based on previous studies, the electricity price, the electricity usage (i.e. net system electrical efficiency), and the uninstalled capital costs were hypothesized to have the greatest impact on the levelized hydrogen cost; therefore, this study focused significant effort on attaining precise values for these parameters. The site preparation costs appeared to have a large uncertainty range, and, within the H2A model, there is a significant discrepancy between the default values for the Forecourt and Central case site preparation costs. Also considered were the replacement interval and replacement costs, which are impacted by the durability of the system to perform over the plant lifetimes assumed.

Based on these input parameters, tornado charts (Figure 4 through Figure 7) were developed for the four cases to examine the impact of individual parameters on hydrogen cost in a single variable sensitivity analysis. The tornado charts plot the levelized hydrogen cost on the $\mathrm{x}$-axis and the single input parameter that is varied on the $\mathrm{y}$-axis. The figures plot the change in $\mathrm{H}_{2}$ cost on the $x$-axis against the change in average electricity price over life of plant, electricity usage, uninstalled capital cost, site preparation cost, stack replacement interval, or stack replacement cost on the y-axis. The tornado charts are organized from top to bottom from the most sensitive input parameters to the least sensitive input parameters, of those analyzed. The colored shading indicates either an increase or a decrease in the baseline hydrogen cost from the change in input parameter. The y-axis lists the low, baseline, and high values for the input parameters, which are also shown in Table 4. Over the range of values and parameters investigated, the tornado charts clearly show that the most sensitive input parameter impacting hydrogen cost is the electricity

\footnotetext{
12 "Reference" scenario selected within the 2009 AEO.

${ }^{13}$ As opposed to alternative AEO electricity classifications of Residential or Commercial.
} 
price. Additional important input parameters include the electricity usage of the electrolyzer (which is proportional to electrolyzer net system electrical efficiency) and the uninstalled capital cost of the electrolyzer.

Table 4. Breakdown of sensitivities for the Forecourt cases (cost results reported in $2007 \$$ and variable limits reported in 2007 and 2012\$)

\begin{tabular}{|c|c|c|c|c|c|c|}
\hline Variable Name & $\begin{array}{l}\text { Low }^{14} \\
\text { Value }\end{array}$ & $\begin{array}{c}\text { Low } \mathrm{H}_{2} \\
\text { Production } \\
\text { Cost } \\
(2007 \$ / \mathrm{kg})\end{array}$ & $\begin{array}{l}\text { Likeliest } \\
\text { Value }\end{array}$ & $\begin{array}{c}\text { Baseline } \mathrm{H}_{2} \\
\text { Production } \\
\text { cost } \\
(2007 \$ / \mathrm{kg})\end{array}$ & $\begin{array}{l}\text { High15 } \\
\text { Value }\end{array}$ & $\begin{array}{l}\text { High } \mathrm{H}_{2} \\
\text { Production } \\
\quad \text { Cost } \\
(2007 \$ / \mathrm{kg})\end{array}$ \\
\hline \multicolumn{7}{|l|}{ Current Forecourt } \\
\hline $\begin{array}{l}\text { Average Electricity Price } \\
\text { over Life of Plant } \\
(2007 \$ / k W h)\end{array}$ & 3.06 & $\$ 3.47$ & 6.12 & $\$ 5.14$ & 9.18 & $\$ 6.81$ \\
\hline $\begin{array}{l}\text { Electricity Usage } \\
(\mathrm{kWh} / \mathrm{kg}) \\
\left(\% \mathrm{LHV} \mathrm{H}_{2}\right)\end{array}$ & $\begin{array}{c}50 \\
(67 \%)\end{array}$ & $\$ 4.71$ & $\begin{array}{c}54.6 \\
(61 \%)\end{array}$ & $\$ 5.14$ & $\begin{array}{c}65 \\
(51 \%)\end{array}$ & $\$ 6.11$ \\
\hline $\begin{array}{l}\text { Uninstalled Capital Costs } \\
(2012 \$ / \mathrm{kW})\end{array}$ & 752 & $\$ 4.79$ & 940 & $\$ 5.14$ & 1,128 & $\$ 5.49$ \\
\hline $\begin{array}{l}\text { Site Prep } \\
\text { (\% of installed capital) }\end{array}$ & $1 \%$ & $\$ 4.95$ & $18.85 \%$ & $\$ 5.14$ & $40 \%$ & $\$ 5.36$ \\
\hline $\begin{array}{l}\text { Replacement Interval } \\
\text { (years) }\end{array}$ & 20 & $\$ 5.04$ & 7 & $\$ 5.14$ & 4 & $\$ 5.25$ \\
\hline $\begin{array}{l}\text { Replacement Costs } \\
\text { (\% of installed capital) }\end{array}$ & $10 \%$ & $\$ 5.11$ & $15 \%$ & $\$ 5.14$ & $25 \%$ & $\$ 5.20$ \\
\hline \multicolumn{7}{|l|}{ Future Forecourt } \\
\hline $\begin{array}{l}\text { Average Electricity Price } \\
\text { over Life of Plant } \\
(2007 \$ / k W h)\end{array}$ & 3.44 & $\$ 2.50$ & 6.88 & $\$ 4.23$ & 10.31 & $\$ 5.96$ \\
\hline $\begin{array}{l}\text { Electricity Usage } \\
(\mathrm{kWh} / \mathrm{kg}) \\
\left(\% \mathrm{LHV} \mathrm{H}_{2}\right)\end{array}$ & $\begin{array}{c}45 \\
(74 \%)\end{array}$ & $\$ 3.79$ & $\begin{array}{c}50.3 \\
(66 \%)\end{array}$ & $\$ 4.23$ & $\begin{array}{c}55 \\
(61 \%)\end{array}$ & $\$ 4.62$ \\
\hline $\begin{array}{l}\text { Uninstalled Capital Costs } \\
(2012 \$ / \mathrm{kW})\end{array}$ & 360 & $\$ 4.08$ & 450 & $\$ 4.23$ & 540 & $\$ 4.37$ \\
\hline $\begin{array}{l}\text { Site Prep } \\
\text { (\% of installed capital) }\end{array}$ & $1 \%$ & $\$ 4.14$ & $18.85 \%$ & $\$ 4.23$ & $40 \%$ & $\$ 4.32$ \\
\hline $\begin{array}{l}\text { Replacement Interval } \\
\text { (years) }\end{array}$ & 20 & $\$ 4.21$ & 10 & $\$ 4.23$ & 4 & $\$ 4.28$ \\
\hline $\begin{array}{l}\text { Replacement Costs } \\
\text { (\% of installed capital) }\end{array}$ & $10 \%$ & $\$ 4.22$ & $12 \%$ & $\$ 4.23$ & $25 \%$ & $\$ 4.24$ \\
\hline
\end{tabular}

14 "Low" reflects the most optimistic parameter value, resulting in a lower $\mathrm{H}_{2}$ production cost.

15 "High" refers to the least optimistic parameter value, resulting in a higher $\mathrm{H}_{2}$ production cost. 
Table 5. Breakdown of sensitivities for the Central cases (cost results reported in $2007 \$$ and variable limits reported in 2007 and 2012\$)

\begin{tabular}{|c|c|c|c|c|c|c|}
\hline Variable Name & $\begin{array}{l}\text { Low } \\
\text { Value }\end{array}$ & $\begin{array}{c}\text { Low } \mathrm{H}_{2} \\
\text { Production } \\
\text { Cost } \\
(2007 \$ / \mathrm{kg})\end{array}$ & $\begin{array}{l}\text { Likeliest } \\
\text { Value }\end{array}$ & $\begin{array}{c}\text { Baseline } \mathrm{H}_{2} \\
\text { Production } \\
\text { cost } \\
(2007 \$ / \mathrm{kg})\end{array}$ & $\begin{array}{l}\text { High } \\
\text { Value }\end{array}$ & $\begin{array}{c}\text { High } \mathrm{H}_{2} \\
\text { Production } \\
\text { Cost } \\
(2007 \$ / \mathrm{kg})\end{array}$ \\
\hline \multicolumn{7}{|l|}{ Current Central } \\
\hline $\begin{array}{l}\text { Average Electricity Price } \\
\text { over Life of Plant } \\
(2007 \$ / k W h)\end{array}$ & 3.11 & $\$ 3.41$ & 6.22 & $\$ 5.12$ & 9.33 & $\$ 6.82$ \\
\hline $\begin{array}{l}\text { Electricity Usage } \\
(\mathrm{kWh} / \mathrm{kg}) \\
\left(\% \mathrm{LHV} \mathrm{H}_{2}\right)\end{array}$ & $\begin{array}{c}50 \\
(67 \%)\end{array}$ & $\$ 4.72$ & $\begin{array}{c}54.3 \\
(61 \%)\end{array}$ & $\$ 5.12$ & $\begin{array}{c}65 \\
(51 \%)\end{array}$ & $\$ 6.12$ \\
\hline $\begin{array}{l}\text { Uninstalled Capital Costs } \\
(2012 \$ / \mathrm{kW})\end{array}$ & 720 & $\$ 4.80$ & 900 & $\$ 5.12$ & 1080 & $\$ 5.45$ \\
\hline $\begin{array}{l}\text { Site Prep } \\
\text { (\% of installed capital) }\end{array}$ & $1 \%$ & $\$ 5.11$ & $2 \%$ & $\$ 5.12$ & $40 \%$ & $\$ 5.49$ \\
\hline $\begin{array}{l}\text { Replacement Interval } \\
\text { (years) }\end{array}$ & 20 & $\$ 5.03$ & 7 & $\$ 5.12$ & 4 & $\$ 5.24$ \\
\hline $\begin{array}{l}\text { Replacement Costs } \\
\text { (\% of installed capital) }\end{array}$ & $10 \%$ & $\$ 5.09$ & $15 \%$ & $\$ 5.12$ & $25 \%$ & $\$ 5.20$ \\
\hline \multicolumn{7}{|l|}{ Future Central } \\
\hline $\begin{array}{l}\text { Average Electricity Price } \\
\text { over Life of Plant } \\
(2007 \$ / k W h)\end{array}$ & 3.45 & $\$ 2.46$ & 6.89 & $\$ 4.20$ & 10.34 & $\$ 5.95$ \\
\hline $\begin{array}{l}\text { Electricity Usage } \\
(\mathrm{kWh} / \mathrm{kg}) \\
\left(\% \mathrm{LHV} \mathrm{H}_{2}\right)\end{array}$ & $\begin{array}{c}45 \\
(74 \%)\end{array}$ & $\$ 3.77$ & $\begin{array}{c}50.2 \\
(66 \%)\end{array}$ & $\$ 4.20$ & $\begin{array}{c}55 \\
(61 \%)\end{array}$ & $\$ 4.59$ \\
\hline $\begin{array}{l}\text { Uninstalled Capital Costs } \\
(2012 \$ / \mathrm{kW})\end{array}$ & 320 & $\$ 4.07$ & 400 & $\$ 4.20$ & 480 & $\$ 4.33$ \\
\hline $\begin{array}{l}\text { Site Prep } \\
\text { (\% of installed capital) }\end{array}$ & $1 \%$ & $\$ 4.19$ & $2 \%$ & $\$ 4.20$ & $40 \%$ & $\$ 4.35$ \\
\hline $\begin{array}{l}\text { Replacement Interval } \\
\text { (years) }\end{array}$ & 20 & $\$ 4.18$ & 10 & $\$ 4.20$ & 4 & $\$ 4.24$ \\
\hline $\begin{array}{l}\text { Replacement Costs } \\
\text { (\% of installed capital) }\end{array}$ & $10 \%$ & $\$ 4.19$ & $12 \%$ & $\$ 4.20$ & $25 \%$ & $\$ 4.22$ \\
\hline
\end{tabular}




\section{Sensitivity Analysis for Current Forecourt PEM Electrolysis $\mathrm{H}_{\mathbf{2}}$ Production}

Average Electricity Price over Life of Plant $(2007 \mathrm{c} / \mathrm{kWh})$

$[3.06,6.12,9.18]$

Electricity Usage $(\mathrm{kWh} / \mathrm{kg})$

$[50,54.6,65]$

$(67 \%, 61 \%, 51 \%)$

Uninstalled Capital Costs (2012\$/kW)

$[752,940,1128]$

Site Prep (\% of installed capital)

$[1 \%, 18.85 \%, 40 \%]$

Replacement Interval (years)

$[20,7,4]$

Replacement Costs (\% of installed capital)

$[10 \%, 15 \%, 25 \%]$

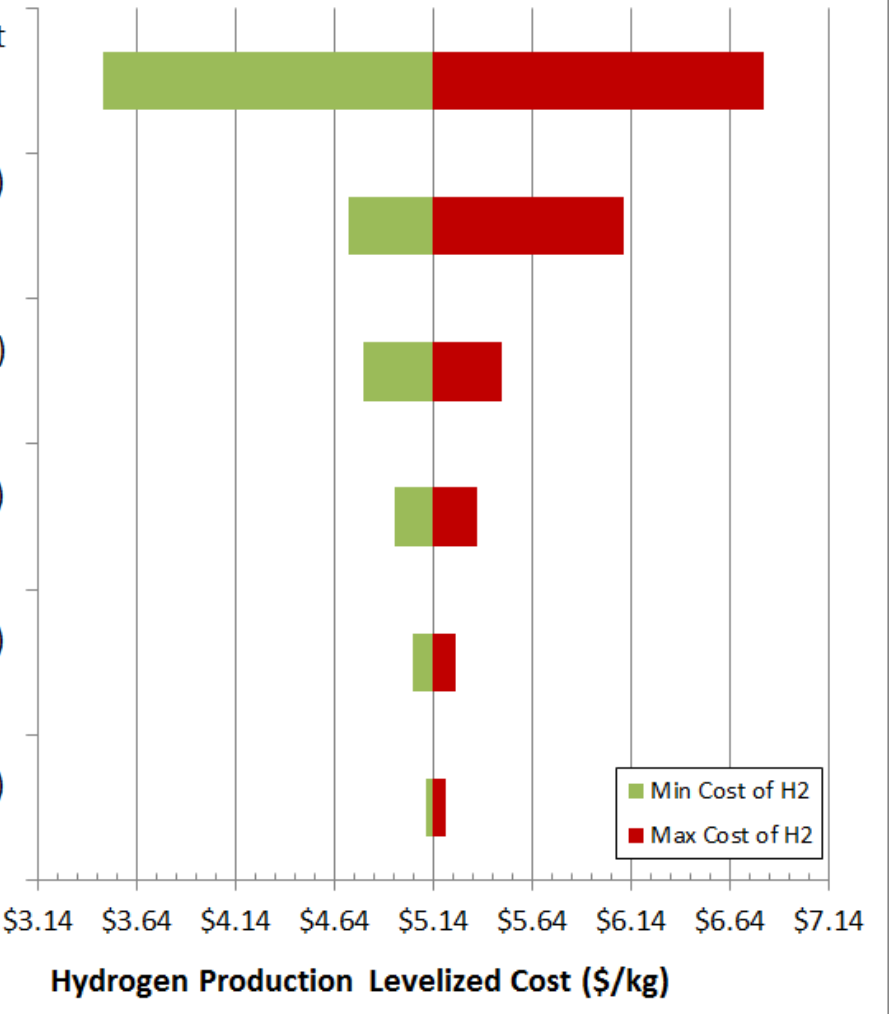

Figure 4. Tornado chart for Current Forecourt case

\section{Sensitivity Analysis for Future Forecourt PEM Electrolysis $\mathrm{H}_{\mathbf{2}}$ Production}

Average Electricity Price over Life of Plant (2007c/kWh)

[3.44, 6.88, 10.31]

Electricity Usage $(\mathrm{kWh} / \mathrm{kg})$ $[45,50.3,55]$ (74\%, 66\%, 61\%)

Uninstalled Capital Costs (2012\$/kW) [360, 450, 540]

Site Prep ( $\%$ of installed capital) [1\%, 18.85\%, 40\%]

Replacement Interval (years) $[20,10,4]$

Replacement Costs (\% of installed capital) [10\%, 12\%, 25\%]

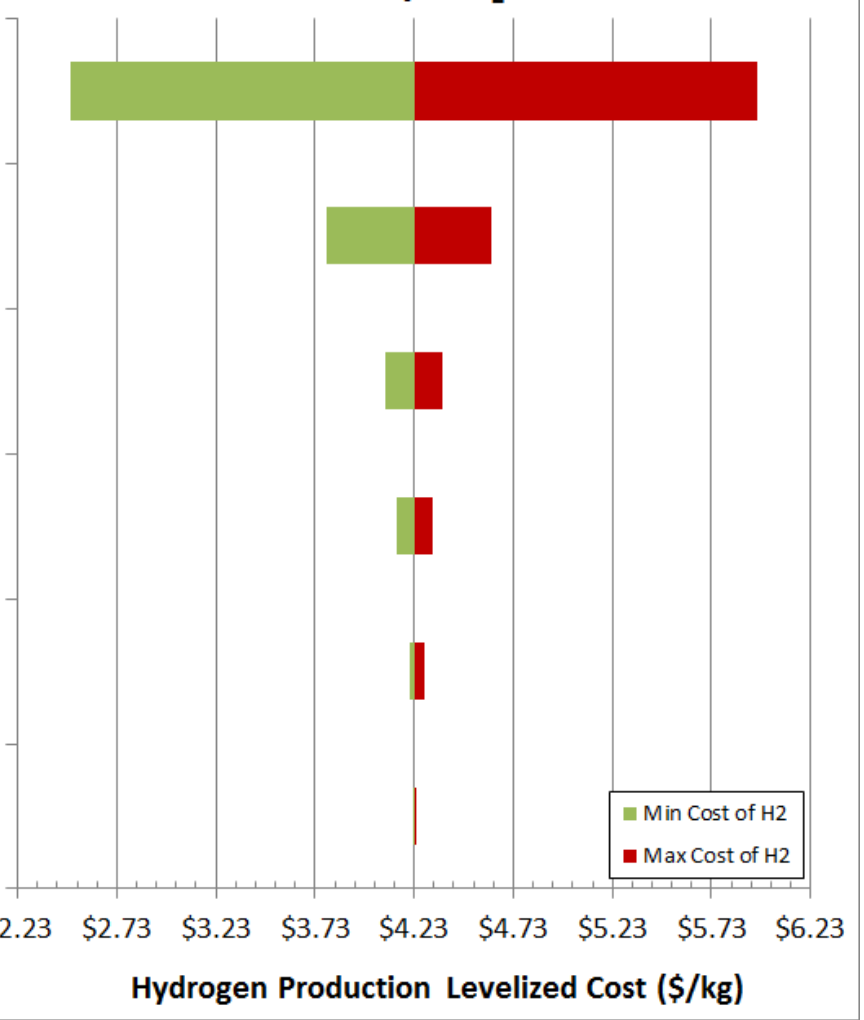

Figure 5. Tornado chart for Future Forecourt case 


\section{Sensitivity Analysis for Current Central PEM Electrolysis $\mathrm{H}_{2}$ Production}

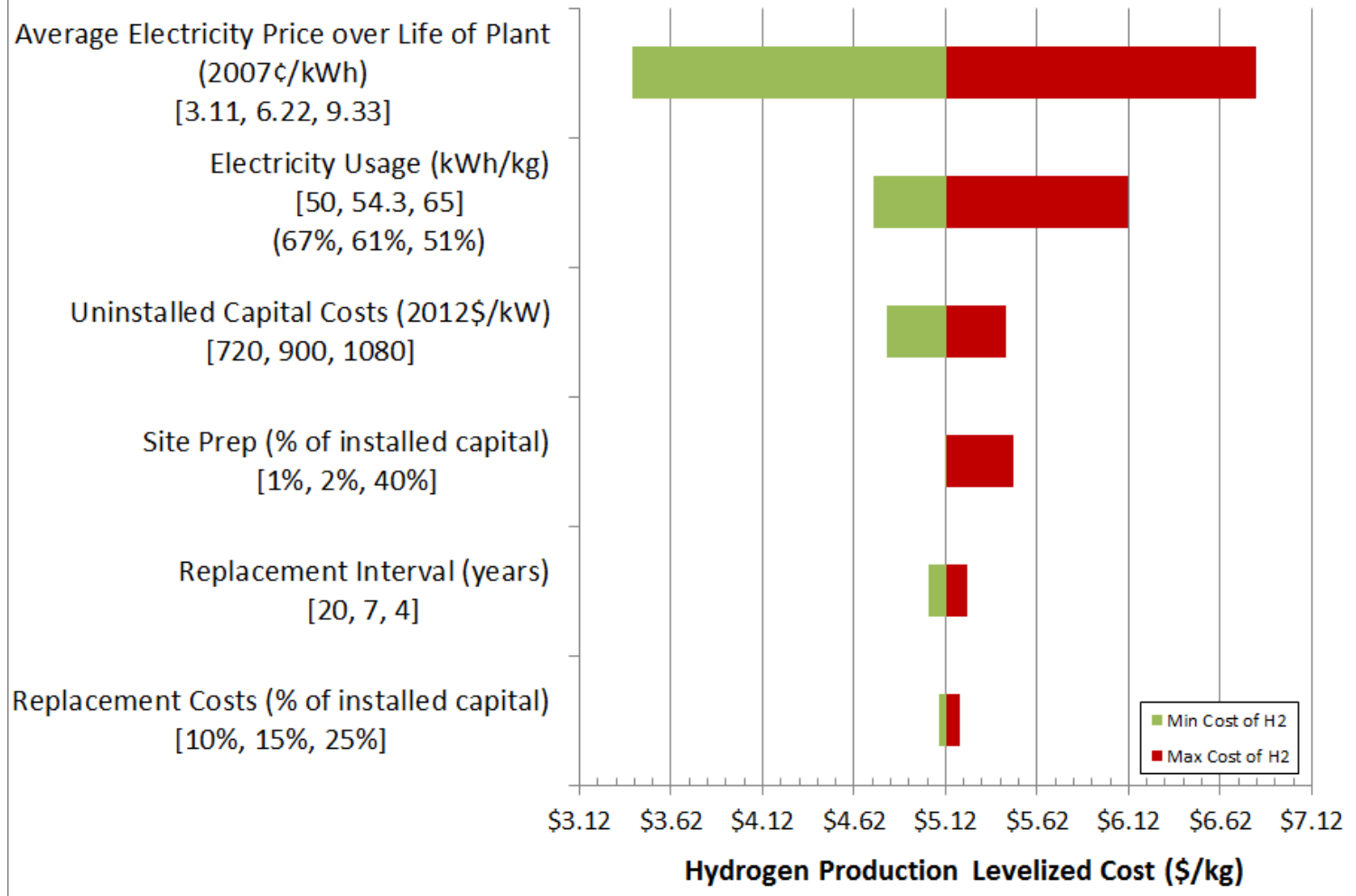

Figure 6. Tornado chart for Current Central case

\section{Sensitivity Analysis for Future Central PEM Electrolysis $\mathrm{H}_{2}$ Production}

Average Electricity Price over Life of Plant (2007c/kWh)

$[3.45,6.89,10.34]$

Electricity Usage (kWh/kg)

$[45,50.2,55]$

$(74 \%, 66 \%, 61 \%)$

Uninstalled Capital Costs (2012\$/kW)

[320, 400, 480]

Site Prep (\% of installed capital) [1\%, 2\%, 40\%]

Replacement Interval (years) $[20,10,4]$

Replacement Costs (\% of installed capital) $[10 \%, 12 \%, 25 \%]$

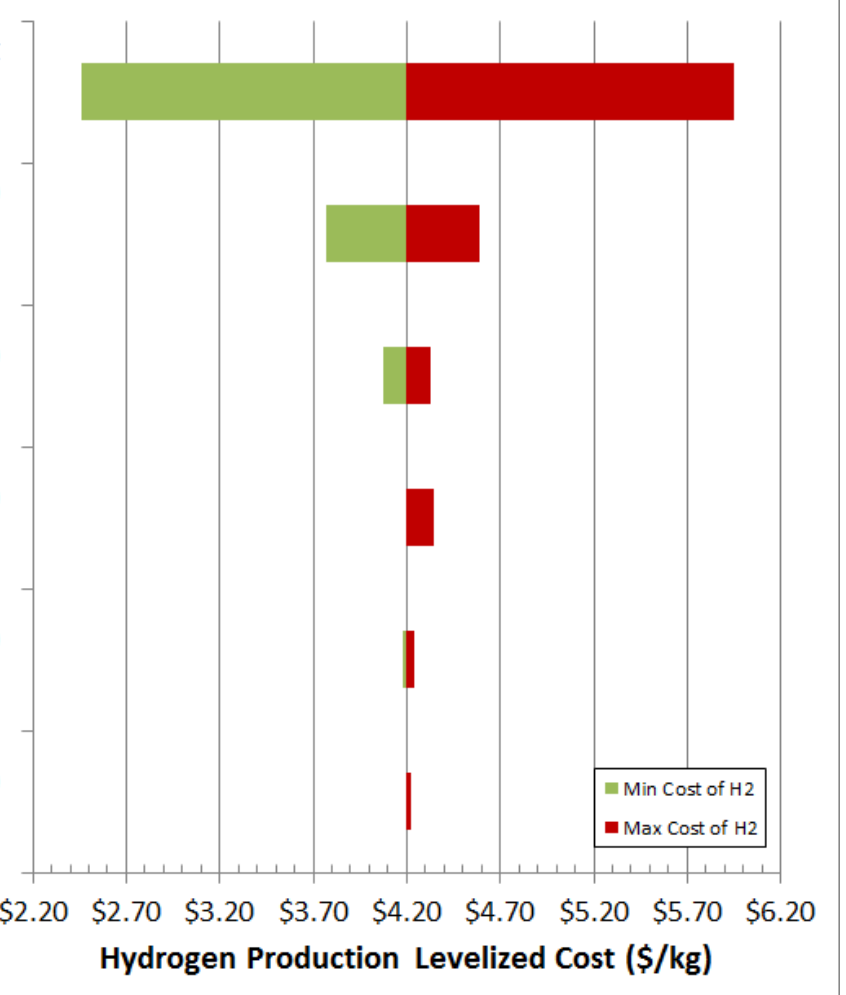

Figure 7. Tornado chart for Future Central case 


\section{Waterfall Charts}

Waterfall charts were created to graphically show the cumulative change in $\mathrm{H}_{2}$ cost corresponding to each parameter change moving from the Current case to the Future case. Figure 8 and Figure 9 show this waterfall chart as applied to the Forecourt and Central cases, respectively. Please note that because electricity prices follow the AEO projections, which vary year by year, and because the Current and Future cases cover different timespans, an increase in electricity price is observed from $6.12 థ / \mathrm{kWh}$ to $6.88 థ / \mathrm{kWh}$ for the forecourt and $6.22 థ / \mathrm{kWh}$ to $6.89 \mathbb{\$} / \mathrm{kWh}$ for the central case which, in turn, increases electricity expenditures for future $\mathrm{H}_{2}$ production. This effect is shown in the second column from the left in the waterfall chart, as an increase of $\$ 0.41 / \mathrm{kg} \mathrm{H}_{2}$ in $\mathrm{H}_{2}$ cost for the Forecourt case, and as an increase of $\$ 0.36 / \mathrm{kg} \mathrm{H}_{2}$ for the Central case. By contrast, the increase in electrical efficiency expected between the Current and Future cases helps reduce net electricity expenditures and bring the $\mathrm{H}_{2}$ production cost down. This effect is shown in the third column from the left in the waterfall chart, as a decrease of $\$ 0.43 / \mathrm{kg} \mathrm{H}_{2}$ in $\mathrm{H}_{2}$ cost for the Forecourt case, and as a decrease of $\$ 0.41 / \mathrm{kg} \mathrm{H}_{2}$ for the Central case. "Other" in the sixth colomn from the left in both Figure 8 and Figure 9 refers to the changes in replacement interval, replacement cost, installation cost factor, and production maintenance and repairs.

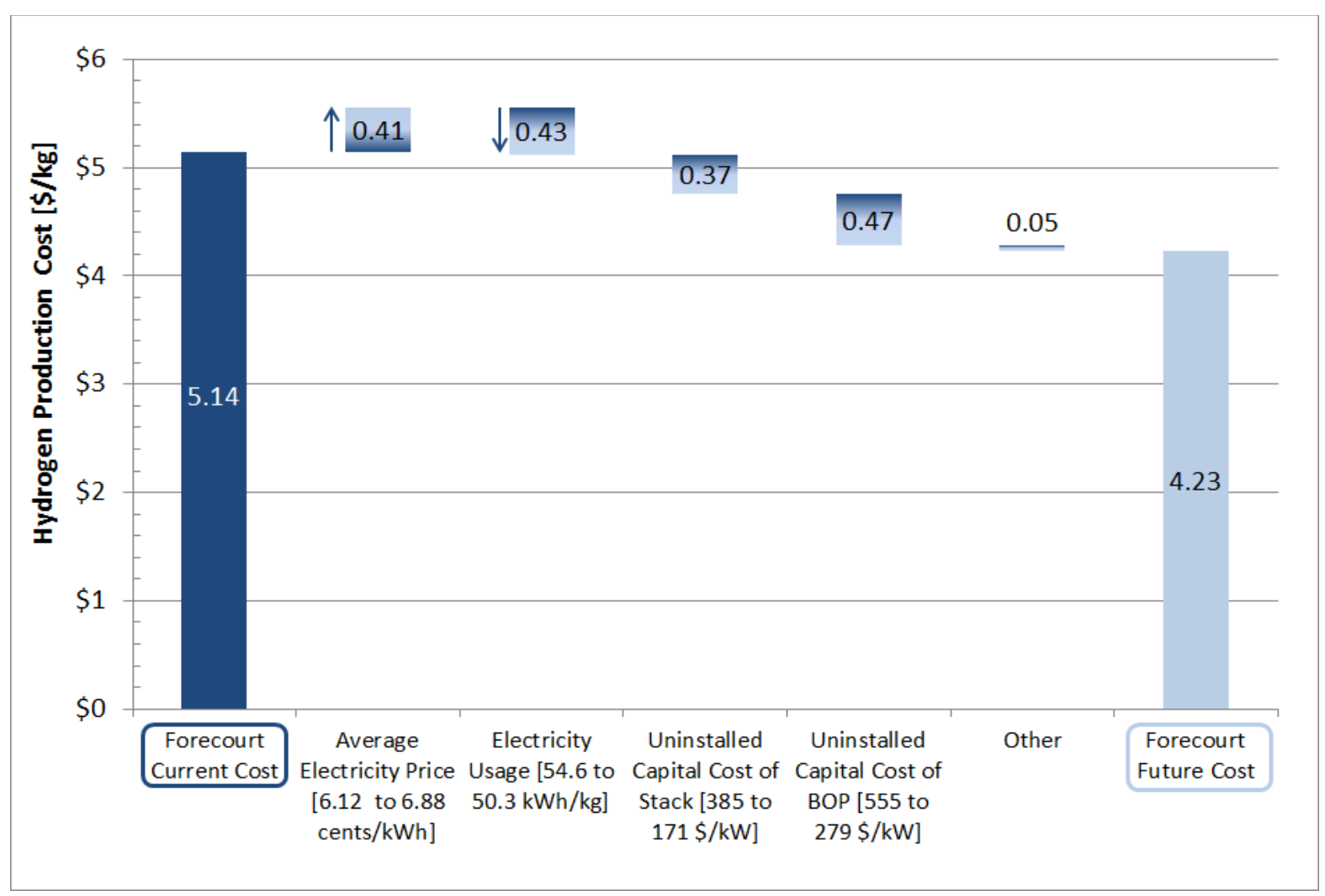

Figure 8. Waterfall chart for the Forecourt case 


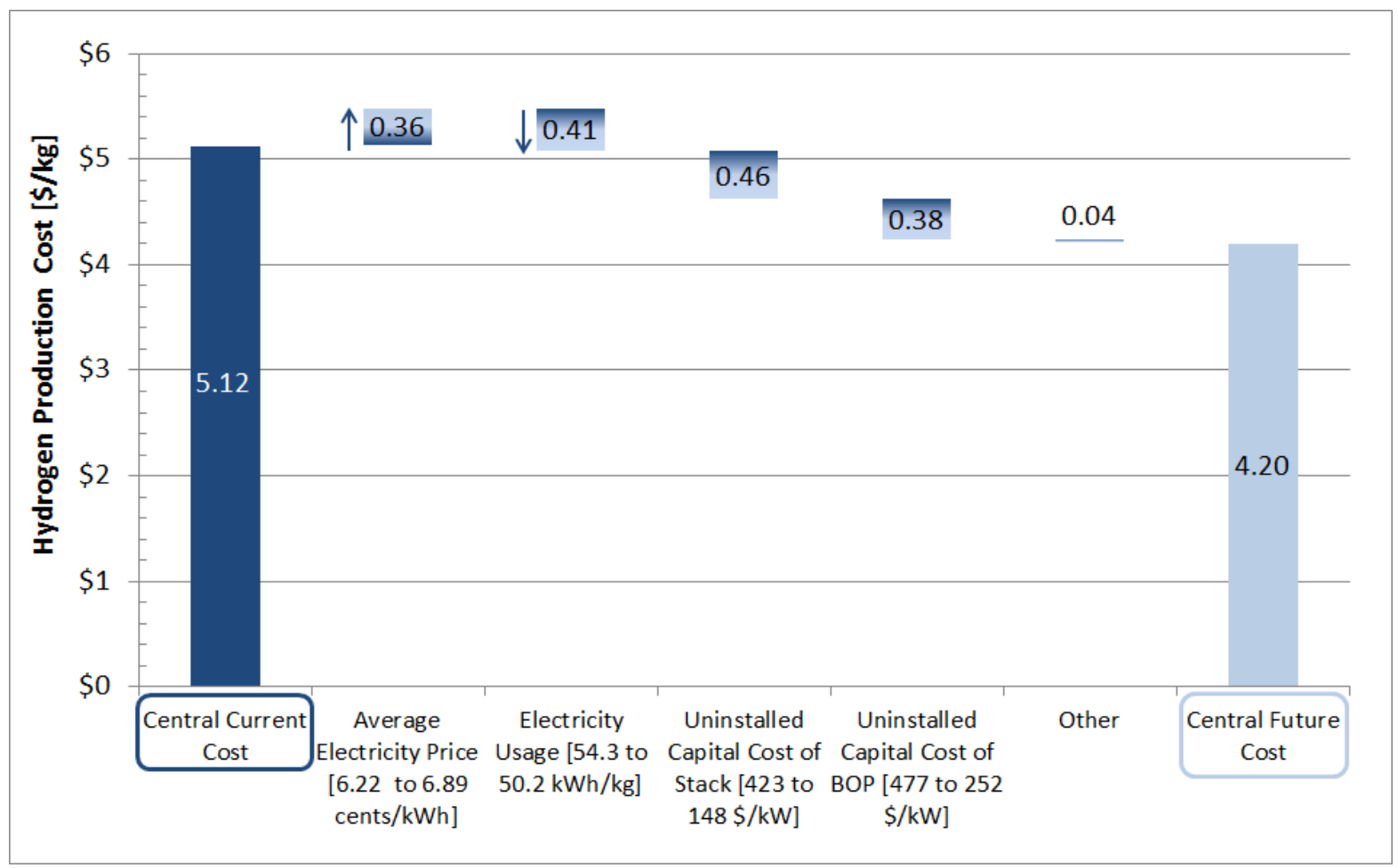

Figure 9. Waterfall chart for the Central case

\section{Cost Drivers}

The greatest cost driver impacting the cost of hydrogen across all cases is the electricity feedstock cost, which is determined by the net system electrical efficiency and the electricity purchase price. The cost of electricity is the leading input variable impacting hydrogen cost, and, while the system efficiency can be improved to some degree, the electricity prices are generally impacted by factors outside of the electrolyzer research and development process. In the sensitivity analyses, the most significant input parameter impacting the cost of hydrogen in these scenarios that could be impacted by the research and development process is the net system electrical efficiency (in units of kilowatt-hours per kilogram $\mathrm{H}_{2}$ ). Either the electrolyzer stack or the balance of plant energy consumption could be improved.

\section{Conclusion}

This research is part of a broad effort to identify the most economical, environmentally benign, and societally feasible paths forward for the production and delivery of $\mathrm{H}_{2}$ fuel for fuel cell vehicles. This report examines $\mathrm{H}_{2}$ production using PEM electrolyzers and discusses primary cost drivers and research and development bottlenecks. Using H2A model runs, four cases are examined in detail: Current Forecourt, Future Forecourt, Current Central, and Future Central. H2A model results indicate that the most sensitive input parameter is the expenditures for electricity input into the electrolyzer. Either lower electricity prices or higher electrolyzer efficiencies can reduce this cost. The second most sensitive input parameter is the uninstalled capital cost of the electrolyzer equipment, including the costs of the electrolyzer stack, the BOP, indirect capital costs, and replacement costs. In the future, within the electrolyzer system, the electrolyzer stack is expected to be operated at higher current densities, and therefore its size and capital cost will be lower. While the electrolyzer stack can be reduced in size and capital cost when it operates at 
higher current densities, the BOP does not see the same proportional reduction in size and capital cost. As a result, under this future scenario, the BOP is expected to be a greater source of capital cost than the electrolyzer stack. This tradeoff between the size and capital cost of the electrolyzer stack compared with the size and capital cost of the BOP is still an area for further analysis and optimization so as to address system efficiency and cost targets. The analysis presented in this report indicates that the reduction in $\mathrm{H}_{2}$ cost is expected to be greater moving from a Current case to a Future case, compared with moving from a Forecourt case to a Central case.

\section{Acknowledgment}

This work was supported by the U.S. Department of Energy, Office of Energy Efficiency and Renewable Energy, Fuel Cell Technologies Office, under award number DE-EE0006231. The authors wish to thank the following individuals for their technical and programmatic contributions and oversight:

- Dr. Eric Miller (Technology Development Manager)

- Dr. Dave Peterson (Technology Development Manager at the Golden Field Office (G0))

- Dr. Sunita Satyapal (Fuel Cell Technologies Office Director)

Support was also provided by: Giner Inc., Hydrogenics Corp., ITM Power, and Proton OnSite. ${ }^{16}$

\section{Selected Bibliography}

- Ayers, K., “Low Cost Large Scale PEM Electrolysis for Renewable Energy Storage," Proton Onsite Presentation at 2013 U.S. Department of Energy Hydrogen and Fuel Cells Program Annual Merit Review, May 15, 2013.

- "Current (2009) State of the Art Hydrogen Production Cost Estimate Using Water Electrolysis: Independent Review," National Renewable Energy Laboratory publication for the U.S. Department of Energy Hydrogen Program, September, 2009. http://www.hydrogen.energy.gov/pdfs/46676.pdf

- Hamdan, M., “PEM Electrolyzer Incorporating an Advanced Low Cost Membrane," Giner Inc. Presentation at 2013 U.S. Department of Energy Hydrogen and Fuel Cells Program Annual Merit Review, May 15, 2013.

- Harrison, K., Peters, M., "Renewable Electrolysis Integrated System Development and Testing," 2013 U.S. Department of Energy Hydrogen and Fuel Cells Program Annual Merit Review, May 15, 2013.

\section{Publically Available Documentation for 2013 PEM Electrolysis H2A Study}

http://www.hydrogen.energy.gov/h2a production documentation.html

- DOE Hydrogen \& Fuel Cells Program Record 14004: H2 Production Cost from PEM Electrolysis

- PEM Electrolysis H2A Cases: Current Forecourt, Future Forecourt, Current Central, and Future Central

\footnotetext{
${ }^{16}$ Industry stakeholder participants voluntarily furnished relevant confidential commercial information to the government in support of the case studies. This commercial information is not publicly available and is customarily held in confidence.
} 


\section{Appendix A. Electrolysis Questionnaire}

Definition of terms:

- "Existing" refers to currently available commercial products, preferably of the highest capacity, to show a lower cost case.

- "Current" refers to current technology, i.e. technology already offered as a product or demonstrated in the laboratory with sufficient confidence that it could be turned into a commercial product with relatively little development risk and with a relatively standard/rapid product development cycle.

- "Future" refers to future technology, i.e. technology that may not be currently demonstrated or even currently defined, but that is expected to be available in a fully functional product in the future year specified. The assumed start-up year is 2025.

- "Mature Market" - For both the Current and Future cases, it is assumed that manufacturing rates may be higher than that currently demonstrated. Thus, the Current and Future cases also apply economies of scale in manufacturing.

Tabs for Forecourt, Central, and Additional Technical Detail are shown in Figure 10, Figure 11, and Figure 12. 


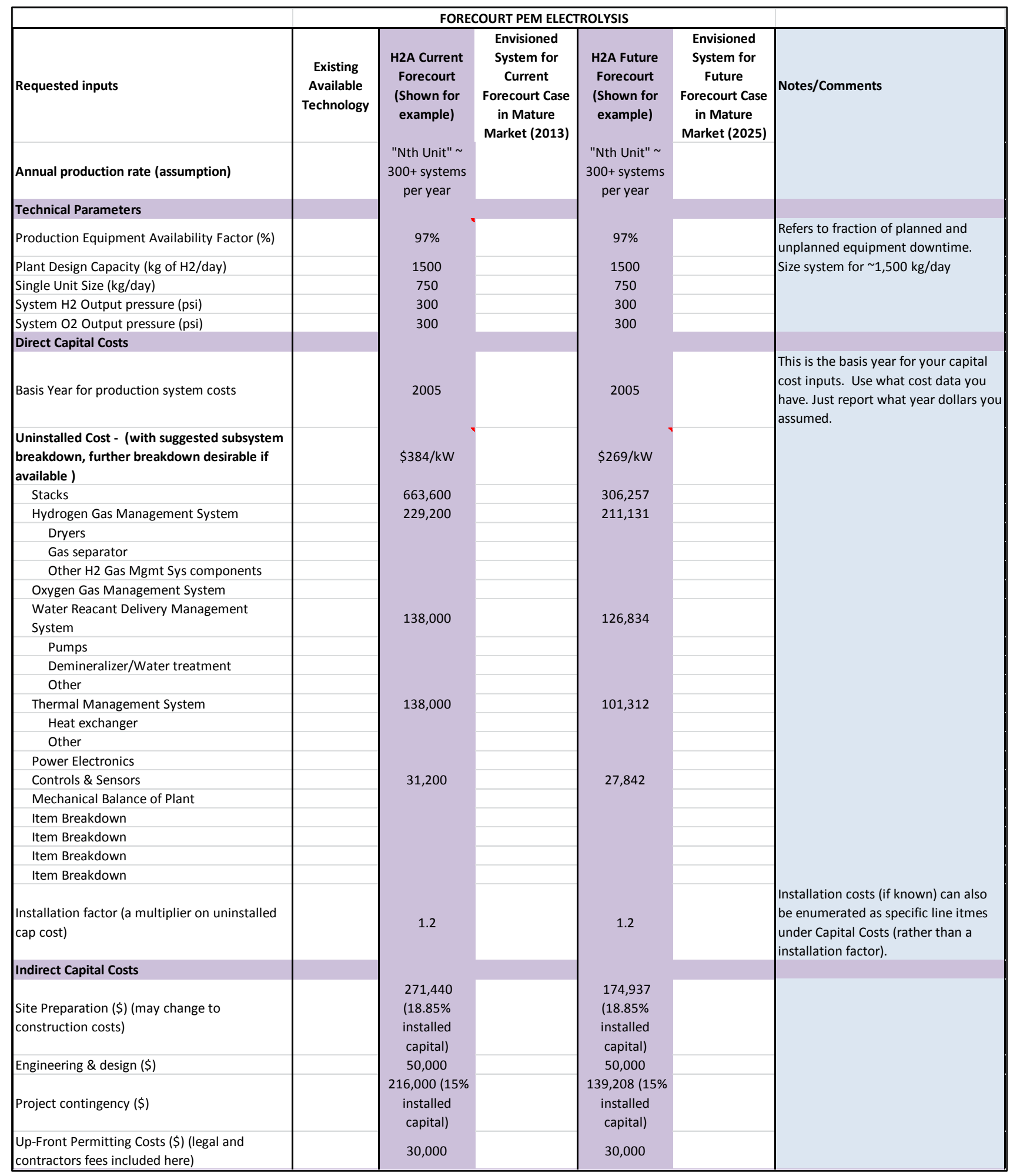

Figure 10. Forecourt case questionnaire tab 


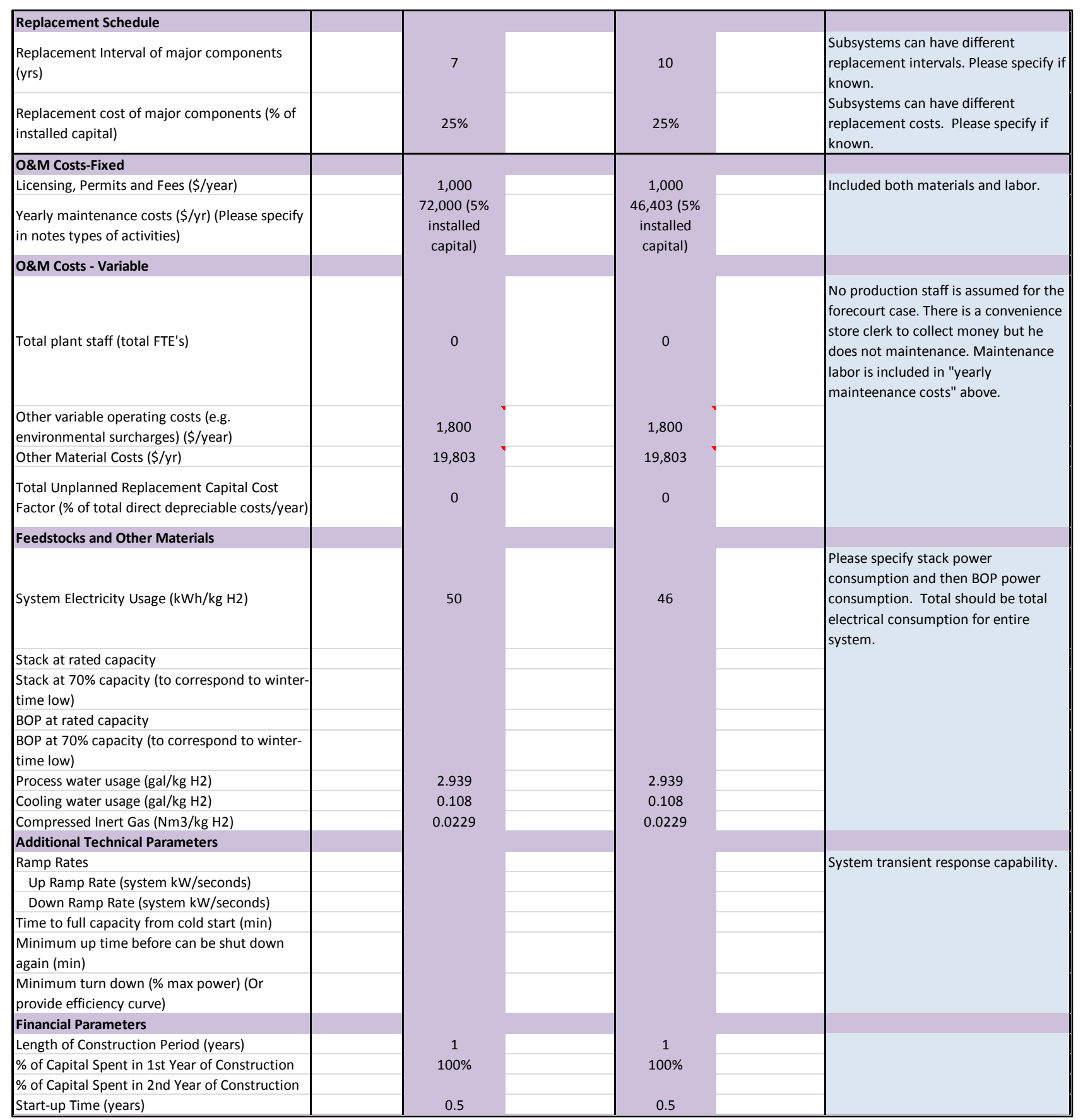

Figure 10. Forecourt case questionnaire tab (continued) 


\begin{tabular}{|c|c|c|c|c|c|}
\hline \multicolumn{5}{|c|}{ Financial Parameters cont'd (The folllowing are H2A default values. The analysis will use these values unless explicitly changed.) } & \multirow{4}{*}{$\begin{array}{l}\text { This is the year the } \$ / \mathrm{kgH} 2 \text { will be } \\
\text { reporting in (i..e 207\$) }\end{array}$} \\
\hline Reference year & 2007 & 2007 & 2007 & 2007 & \\
\hline Assumed start-up year & 2010 & 2010 & 2025 & 2025 & \\
\hline Plant life (years) & 20 & 20 & 20 & 20 & \\
\hline Analysis period (years) & 20 & 20 & 20 & 20 & $\begin{array}{l}\text { Use H2A default values. If you have } \\
\text { strong disagreement, then we can } \\
\text { discuss. }\end{array}$ \\
\hline Depreciation Schedule Length (years) & 7 & 7 & 7 & 7 & $\begin{array}{l}\text { Use H2A default values. If you have } \\
\text { strong disagreement, then we can } \\
\text { discuss. }\end{array}$ \\
\hline Depreciation Type & MACRS & MACRS & MACRS & MACRS & $\begin{array}{l}\text { Use H2A default values. If you have } \\
\text { strong disagreement, then we can } \\
\text { discuss. }\end{array}$ \\
\hline$\%$ Equity Financing & 1 & 1 & 1 & 1 & $\begin{array}{l}\text { Use H2A default values. If you have } \\
\text { strong disagreement, then we can } \\
\text { discuss. }\end{array}$ \\
\hline$\%$ of Fixed Operating Costs During Start-up (\%) & 0.75 & 0.75 & 0.75 & 0.75 & $\begin{array}{l}\text { Use H2A default values. If you have } \\
\text { strong disagreement, then we can } \\
\text { discuss. }\end{array}$ \\
\hline$\%$ of Revenues During Start-up (\%) & $50 \%$ & $50 \%$ & $50 \%$ & $50 \%$ & $\begin{array}{l}\text { Use H2A default values. If you have } \\
\text { strong disagreement, then we can } \\
\text { discuss. }\end{array}$ \\
\hline $\begin{array}{l}\% \text { of Variable Operating Costs During Start-up } \\
\text { (\%) }\end{array}$ & $50 \%$ & $50 \%$ & $50 \%$ & $50 \%$ & $\begin{array}{l}\text { Use H2A default values. If you have } \\
\text { strong disagreement, then we can } \\
\text { discuss. }\end{array}$ \\
\hline $\begin{array}{l}\text { Decommissioning costs (\% of depreciable } \\
\text { capital investment) }\end{array}$ & $10 \%$ & $10 \%$ & $10 \%$ & $10 \%$ & $\begin{array}{l}\text { Use H2A default values. If you have } \\
\text { strong disagreement, then we can } \\
\text { discuss. }\end{array}$ \\
\hline Salvage value (\% of total capital investment) & $10 \%$ & $10 \%$ & $10 \%$ & $10 \%$ & $\begin{array}{l}\text { Use H2A default values. If you have } \\
\text { strong disagreement, then we can } \\
\text { discuss. }\end{array}$ \\
\hline Inflation rate $(\%)$ & $2 \%$ & $2 \%$ & $2 \%$ & $2 \%$ & $\begin{array}{l}\text { Use H2A default values. If you have } \\
\text { strong disagreement, then we can } \\
\text { discuss. }\end{array}$ \\
\hline After-tax Real IRR (\%) & $10 \%$ & $10 \%$ & $10 \%$ & $10 \%$ & $\begin{array}{l}\text { Use H2A default values. If you have } \\
\text { strong disagreement, then we can } \\
\text { discuss. }\end{array}$ \\
\hline State Taxes (\%) & $6 \%$ & $6 \%$ & $6 \%$ & $6 \%$ & $\begin{array}{l}\text { Use H2A default values. If you have } \\
\text { strong disagreement, then we can } \\
\text { discuss. }\end{array}$ \\
\hline Federal Taxes (\%) & $35 \%$ & $35 \%$ & $35 \%$ & $35 \%$ & $\begin{array}{l}\text { Use H2A default values. If you have } \\
\text { strong disagreement, then we can } \\
\text { discuss. }\end{array}$ \\
\hline $\begin{array}{l}\text { WORKING CAPITAL (\% of yearly change in } \\
\text { operating costs) }\end{array}$ & $1 \%$ & $1 \%$ & $1 \%$ & $1 \%$ & $\begin{array}{l}\text { Use H2A default values. If you have } \\
\text { strong disagreement, then we can } \\
\text { discuss. }\end{array}$ \\
\hline
\end{tabular}

Figure 10. Forecourt case questionnaire tab (continued) 


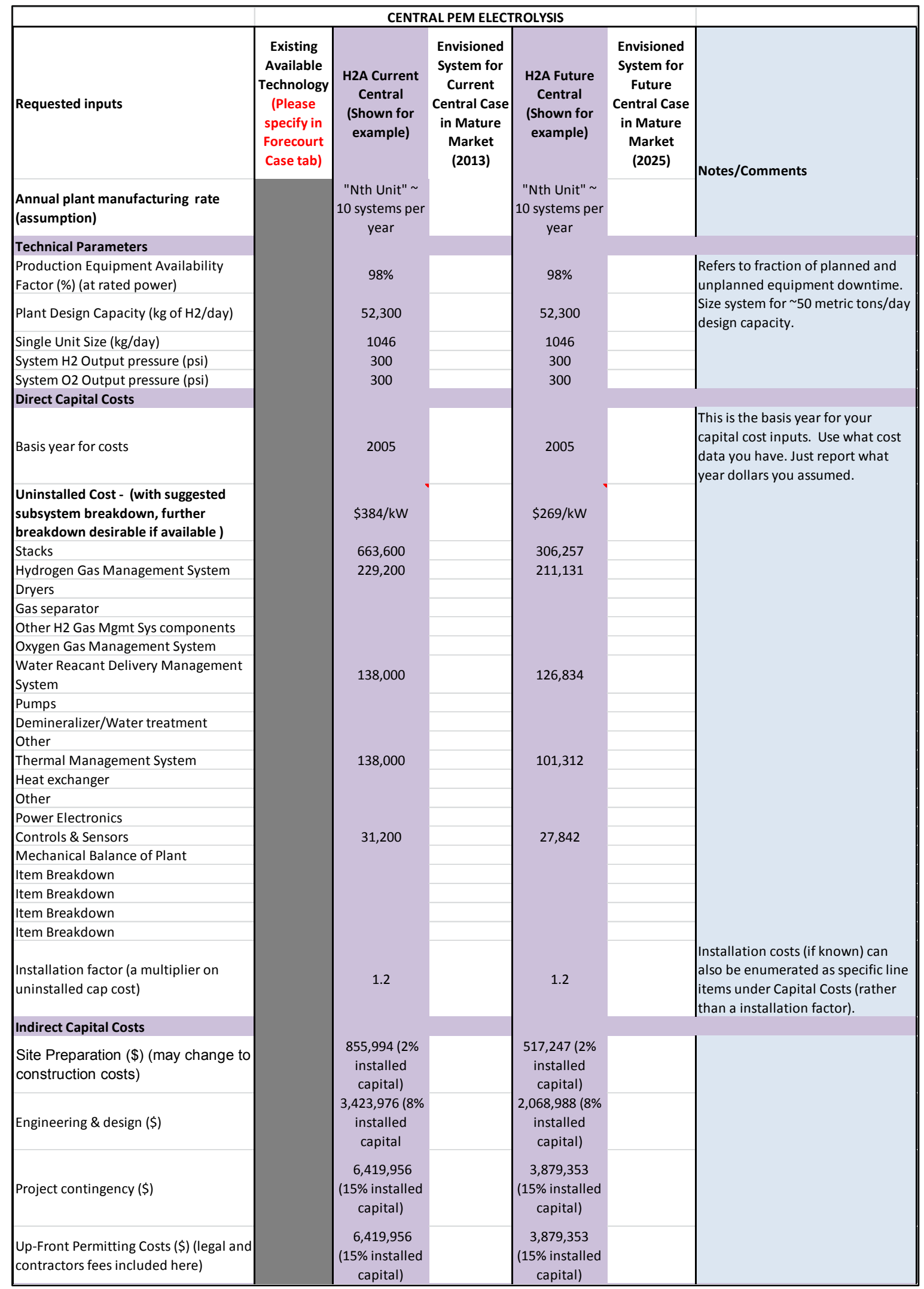

Figure 11. Central case questionnaire tab 


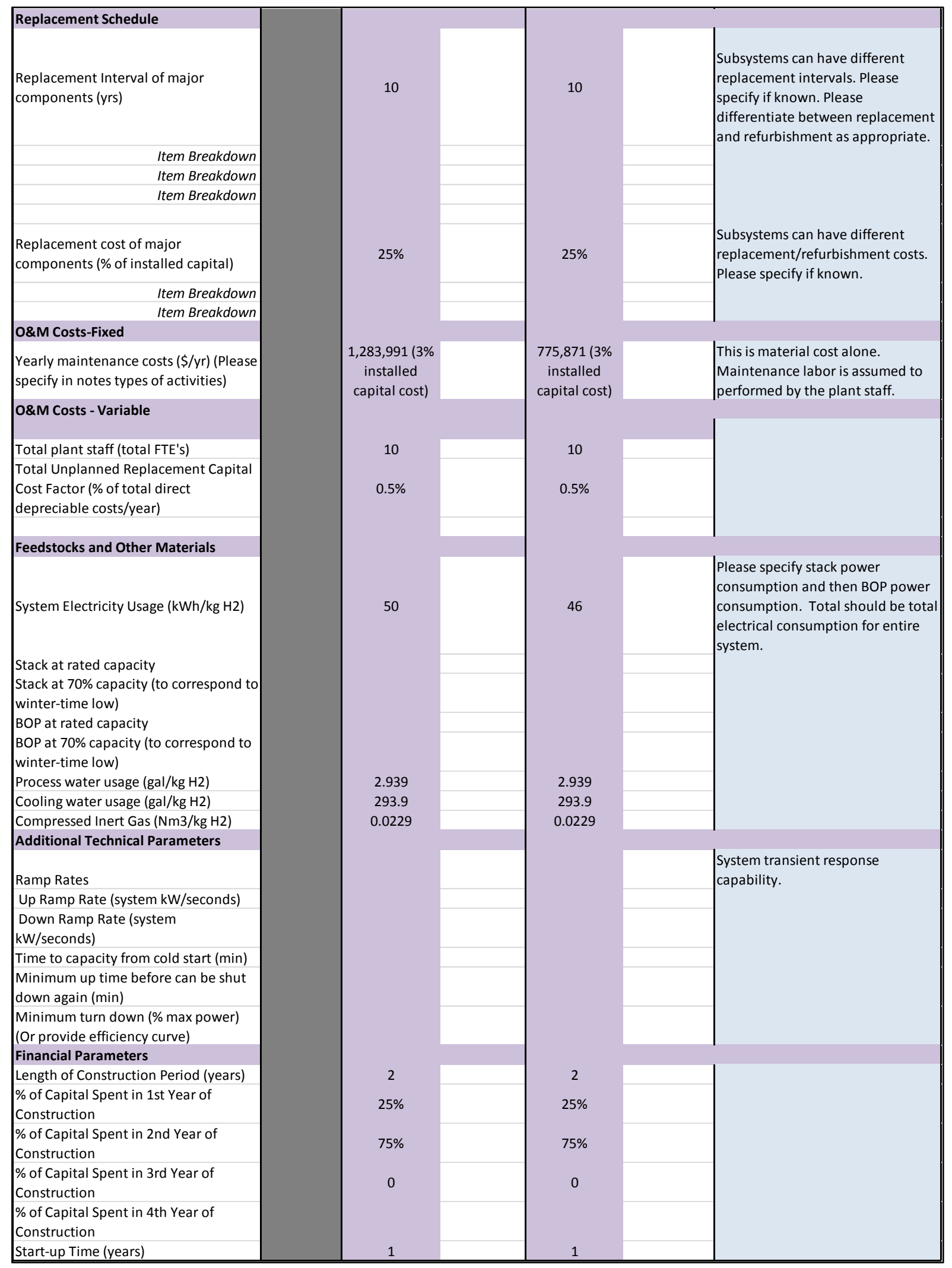

Figure 11. Central case questionnaire tab (continued) 


\begin{tabular}{|c|c|c|c|c|c|}
\hline \multicolumn{6}{|c|}{ Financial Parameters cont'd (The folllowing are H2A default values. The analysis will use these values unless explicitly changed.) } \\
\hline Reference year & 2007 & 2007 & 2007 & 2007 & $\begin{array}{l}\text { This is the year the } \$ / \mathrm{kgH} 2 \text { will be } \\
\text { reporting in (i.e } 207 \$ \text { ) }\end{array}$ \\
\hline Assumed start-up year & 2010 & 2010 & 2025 & 2025 & \\
\hline Plant life (years) & 40 & 40 & 40 & 40 & \\
\hline Analysis period (years) & 40 & 40 & 40 & 40 & $\begin{array}{l}\text { Use H2A default values. If you have } \\
\text { strong disagreement, then we can } \\
\text { discuss. }\end{array}$ \\
\hline Depreciation Schedule Length (years) & 20 & 20 & 20 & 20 & $\begin{array}{l}\text { Use H2A default values. If you have } \\
\text { strong disagreement, then we can } \\
\text { discuss. }\end{array}$ \\
\hline Depreciation Type & MACRS & MACRS & MACRS & MACRS & $\begin{array}{l}\text { Use } \mathrm{H} 2 \mathrm{~A} \text { default values. If you have } \\
\text { strong disagreement, then we can } \\
\text { discuss. }\end{array}$ \\
\hline \% Equity Financing & $100 \%$ & $100 \%$ & $100 \%$ & $100 \%$ & $\begin{array}{l}\text { Use H2A default values. If you have } \\
\text { strong disagreement, then we can } \\
\text { discuss. }\end{array}$ \\
\hline Interest rate on debt, if applicable (\%) & 0 & 0 & 0 & 0 & $\begin{array}{l}\text { Use H2A default values. If you have } \\
\text { strong disagreement, then we can } \\
\text { discuss. }\end{array}$ \\
\hline Debt period (years) & 0 & 0 & 0 & 0 & $\begin{array}{l}\text { Use H2A default values. If you have } \\
\text { strong disagreement, then we can } \\
\text { discuss. }\end{array}$ \\
\hline $\begin{array}{l}\% \text { of Fixed Operating Costs During Start- } \\
\text { up (\%) }\end{array}$ & $100 \%$ & $100 \%$ & $100 \%$ & $100 \%$ & $\begin{array}{l}\text { Use H2A default values. If you have } \\
\text { strong disagreement, then we can } \\
\text { discuss. }\end{array}$ \\
\hline$\%$ of Revenues During Start-up (\%) & $50 \%$ & $50 \%$ & $50 \%$ & $50 \%$ & $\begin{array}{l}\text { Use H2A default values. If you have } \\
\text { strong disagreement, then we can } \\
\text { discuss. }\end{array}$ \\
\hline $\begin{array}{l}\% \text { of Variable Operating Costs During } \\
\text { Start-up (\%) }\end{array}$ & $75 \%$ & $75 \%$ & $75 \%$ & $75 \%$ & $\begin{array}{l}\text { Use H2A default values. If you have } \\
\text { strong disagreement, then we can } \\
\text { discuss. }\end{array}$ \\
\hline $\begin{array}{l}\text { Decommissioning costs (\% of } \\
\text { depreciable capital investment) }\end{array}$ & $10 \%$ & $10 \%$ & $10 \%$ & $10 \%$ & $\begin{array}{l}\text { Use } \mathrm{H} 2 \mathrm{~A} \text { default values. If you have } \\
\text { strong disagreement, then we can } \\
\text { discuss. }\end{array}$ \\
\hline $\begin{array}{l}\text { Salvage value (\% of total capital } \\
\text { investment) }\end{array}$ & $10 \%$ & $10 \%$ & $10 \%$ & $10 \%$ & $\begin{array}{l}\text { Use H2A default values. If you have } \\
\text { strong disagreement, then we can } \\
\text { discuss. }\end{array}$ \\
\hline Inflation rate (\%) & $2 \%$ & $2 \%$ & $2 \%$ & $2 \%$ & $\begin{array}{l}\text { Use H2A default values. If you have } \\
\text { strong disagreement, then we can } \\
\text { discuss. }\end{array}$ \\
\hline After-tax Real IRR (\%) & $10 \%$ & $10 \%$ & $10 \%$ & $10 \%$ & $\begin{array}{l}\text { Use H2A default values. If you have } \\
\text { strong disagreement, then we can } \\
\text { discuss. }\end{array}$ \\
\hline State Taxes (\%) & $6 \%$ & $6 \%$ & $6 \%$ & $6 \%$ & $\begin{array}{l}\text { Use H2A default values. If you have } \\
\text { strong disagreement, then we can } \\
\text { discuss. }\end{array}$ \\
\hline Federal Taxes (\%) & $35 \%$ & $35 \%$ & $35 \%$ & $35 \%$ & $\begin{array}{l}\text { Use H2A default values. If you have } \\
\text { strong disagreement, then we can } \\
\text { discuss. }\end{array}$ \\
\hline $\begin{array}{l}\text { WORKING CAPITAL (\% of yearly change } \\
\text { in operating costs) }\end{array}$ & $5 \%$ & $5 \%$ & $5 \%$ & $5 \%$ & $\begin{array}{l}\text { Use H2A default values. If you have } \\
\text { strong disagreement, then we can } \\
\text { discuss. }\end{array}$ \\
\hline
\end{tabular}

Figure 11. Central case questionnaire tab (continued) 


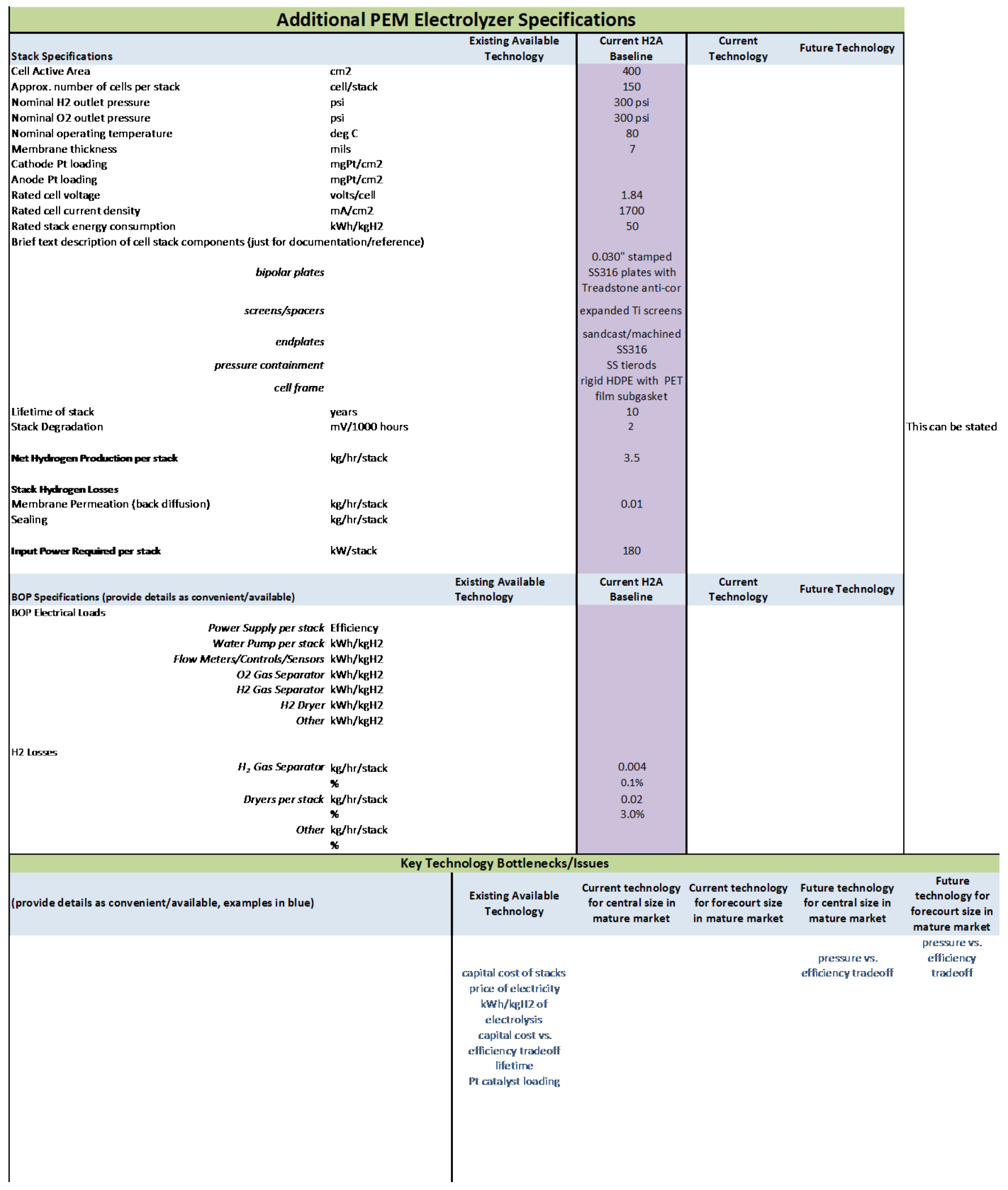

Figure 12. Additional Technical Detail questionnaire tab 